\title{
CABALLERÍA Y NOBLEZA EN LA ORDEN DE CALATRAVA: CASTILLA, 1350-1450
}

\author{
KNIGHTHOOD AND NOBILITY IN THE MILITARY ORDER OF CALATRAVA: \\ CASTILE, 1350-1450
}

\section{ENRIQUe RodRíGUEZ-PICAVEA MATILla Universidad Autónoma de Madrid}

\begin{abstract}
Resumen: El artículo analiza la relación existente entre los caballeros de la orden militar de Calatrava y los linajes nobiliarios castellanos entre mediados del siglo XIV y mediados del siglo XV. Para ello se combina la información cronística con la documentación archivística procedente del Archivo Histórico Nacional y de la Real Academia de la Historia. El resultado de la investigación es que la mayoría de los caballeros calatravos procedían de las filas de la baja nobleza, con particular referencia a las oligarquías urbanas de Toledo, Córdoba y Sevilla. Sin embargo, fueron generalmente los freires procedentes de la alta nobleza y de la nobleza media los que controlaron el triunvirato de poder de la orden y las encomiendas más importantes.
\end{abstract}

Palabras clave: Caballería; Nobleza; Órdenes militares; Orden de Calatrava; Castilla; Siglos XIV y XV.

\begin{abstract}
The article analyzes the relationship between the Calatrava Order's knighthood and the Castilian noble families, since the middle of 14th century to the middle of 15th century. This work is based on the study of chronicles and also on the records conserved in the Archivo Histórico Nacional and in the Real Academia de la Historia (Madrid). The result of this research has been that the majority of Calatrava Knights belonged to the low nobility, especially to the urban oligarchy of Toledo, Córdoba and Sevilla. Nevertheless, the control of the Order and the most of its Commanderies were in the hands of Friars who belonged to high and middle nobility.
\end{abstract}

Key words: Knighthood; Nobility; Military Orders; Military Order of Calatrava; Castile; 14th and 15th centuries.

\section{SUMARIO}

1. Los freires calatravos: cuantificación de efectivos y clasificación.- 2. Los linajes introducidos en la orden de Calatrava.- 3. Sociología de los linajes calatravos.- 4. Familias nobiliarias castellanas y dominio de la orden de Calatrava.- 5 . Las encomiendas y el reparto del patrimonio calatravo.- 6. Las encomiendas y la cuestión de la herencia.- Conclusiones

Al llegar al ecuador del siglo XIV, la orden de Calatrava se encontraba inmersa en un proceso aristocratización, que estaba propiciando la difusión de los valores nobiliarios en el seno de una institución religiosa. No es desde luego una casualidad que a partir de 1350 sea posible detectar en la documentación la vinculación de no pocos caballeros calatravos con 
determinados linajes nobiliarios castellanos. Los cien años siguientes contemplaron la introducción y consolidación de nuevas familias nobiliarias, que contribuyeron así al reforzamiento del proceso secularizador.

Teniendo en cuenta lo anteriormente expuesto, en este trabajo analizaremos la relación existente entre los caballeros de la orden militar de Calatrava y los linajes nobiliarios castellanos entre mediados del siglo XIV y mediados del siglo XV. Para ello empezaremos con la cuantificación de los freires calatravos y su clasificación, seguiremos con el estudio de los linajes introducidos en la institución, su sociología y el control que establecen sobre la orden. Para finalizar, nos detendremos en el análisis de las encomiendas calatravas, el reparto de los recursos de la institución entre las familias nobiliarias y la cuestión de la posible herencia comendataria.

\section{LOS FREIRES CALATRAVOS: CUANTIFICACIÓN DE EFECTIVOS Y CLASIFICACIÓN}

La documentación utilizada para la elaboración de esta investigación ${ }^{1}$ ha permitido identificar a 320 freires calatravos diferentes durante el período comprendido entre 1350 y 1450 y únicamente con relación al ámbito castellano. De ellos, 258 son freires caballeros, 56 son freires clérigos y seis son freires de condición imprecisa, ya que la documentación no aporta datos que permitan identificarlos como caballeros o clérigos. Es decir un mínimo de $80 \%$ de caballeros frente a, como mucho, un $20 \%$ de freires pertenecientes al brazo clerical, suponiendo que los 6 freires de condición imprecisa fueran efectivamente clérigos.

Sin embargo, es posible introducir algunas matizaciones en las cifras que acabamos de ofrecer. Lógicamente no se trata de cifras absolutas. Sin duda alguna hubo entre mediados del siglo XIV y mediados del siglo XV más freires calatravos que los que hemos conseguido documentar. Por otra parte, importa subrayar que los clérigos parecen estar peor documentados que los caballeros, muy especialmente durante el tercer cuarto del siglo XIV. En consecuencia cabría corregir ligeramente al alza el porcentaje de freires calatravos integrantes del brazo clerical.

Con todo, y pese a estas matizaciones, el predominio numérico del brazo secular sobre el clerical era abrumador ${ }^{2}$. En este período la orden es una

${ }^{1}$ La parte fundamental de la documentación utilizada procede del antiguo archivo del convento de Calatrava, actualmente ubicado en el Archivo Histórico Nacional (Madrid), Sección de Ordenes Militares. En menor medida hemos trabajado también con las copias documentales de la Colección Salazar que custodia la Real Academia de la Historia, en Madrid.

${ }^{2}$ Parece que esta diferencia cuantitativa y cualitativa entre los freires clérigos y los caballeros se produjo desde los orígenes de la orden calatrava. Vid. C. AYALA MARTINEZ, Las órdenes militares hispánicas en la Edad Media (siglos XII-XV), Madrid, 2003, pp. 167-170. 
institución que experimenta un intenso proceso de aristocratización ${ }^{3}$ y el elemento clerical ocupa una posición cada vez más marginal. Las encomiendas laicas eran las más importantes y ambicionadas por la nobleza castellana, ya que se trataba indiscutiblemente de las que generaban unas rentas más cuantiosas. Esta supremacía de la rama militar sobre la rama eclesiástica de la orden se constata también en la percepción de diezmos por parte de la mesa maestral y en las competencias para la provisión de prioratos con las que contaba el maestre, figura que encarna el triunfo de los elementos laicos frente a los religiosos ${ }^{4}$.

Sobre el origen social de los clérigos calatravos nada podemos decir, ya que la documentación se refiere a ellos solamente por el nombre, seguido en algunos casos del lugar de nacimiento o procedencia. Sólo conocemos este último dato referido a 20 de los freires clérigos calatravos. La procedencia de estos clérigos del Campo de Calatrava, señorío nuclear y principal de la orden, resulta ciertamente la más relevante; en concreto 15 de los clérigos calatravos proceden de esta comarca, las tres cuartas partes del total de estos freires entre los que conocemos su origen, particularmente de Almodóvar (7) ${ }^{5}$ y Almagro (4) ${ }^{6}$, las dos villas más importantes de la zona en el período que estamos analizando, mientras que otros cuatro freires proceden de Calzada, Moral, Bolaños y Valdepeñas, todas ellas poblaciones también del Campo de Calatrava. Los restantes clérigos con procedencia conocida vienen del reino de Toledo (2), de Andalucía Bética (2) y del reino de Valencia (1) ${ }^{7}$.

${ }^{3}$ C. Ayala Martínez, Comendadores y encomiendas. Orígenes y evolución en las órdenes militares castellano-leonesas de la Edad Media, en Ordens Militares. Guerra, religiao, poder e cultura. "Actas do III Encontro sobre Ordens Militares", Lisboa-Palmela, 1999, I, 101-147, pp. 142-147.

${ }^{4}$ E. RodríGueZ-PICAVEa Matilla, La nobleza y la Orden de Calatrava en tiempos de Juan II de Castilla, en As Ordens Militares e de Cavalaria na Construcao do Mundo Ocidental. "Actas do IV Encontro sobre Ordens Militares", Lisboa, 2005, 585-620, pp. 676-677. Como constatación de esta supremacía maestral, en 1433 el abad de Morimond determinaba que el maestre (superius in Ordine) fuera el máximo responsable de la ejecución de las Definiciones, por encima del prior, el clavero y el sacristán. Vid. Archivo Histórico Nacional, Ordenes Militares (en adelante AHN, OO. MM.), sign. 1348 c, Registro de Escrituras de la Orden de Calatrava, VIII, fols. 66-73.

${ }^{5}$ AHN, OO. MM., Calatrava, carp. 449, no 127; AHN, OO. MM., sign. 1348 c, Registro de Escrituras de la Orden de Calatrava, VIII, fol. 87; RAH, Colección Salazar, sign. İ-38, fols. 99-100r; AHN, OO. MM., Calatrava, carp. 467, no 321 bis y carp. 468, n⿳ 328,333 y 338 AHN, OO. MM., Consejo, Calatrava, leg. 6.109, $\mathrm{n}^{\mathrm{O}} 3$; AHN, Nobleza, C. 2, no 1 ; C. TORRES SUÁREZ, Don Rodrigo Téllez Girón, maestre de Calatrava, "Anuario de Estudios Medievales", 11 (1981), 775-792, pp. 787-788; CAASADO QUINTANILLA, Corona de Castilla: Documentos de la Orden de Calatrava expedidos durante los tres últimos maestrazgos (1445-1489). Estudio diplomático, Madrid, 1997, n⿳0 23; AHN, OO. MM., Calatrava, carp. 469, n⿳0 357 y 358.

${ }^{6} \mathrm{AHN}$, OO. MM., Calatrava carp. $467, \mathrm{n}^{\mathrm{o}} 321$ bis y carp. $469, \mathrm{n}^{\mathrm{o}} 358 ; \mathrm{J}$. M ${ }^{\mathrm{a}}$. PONTES Y FERNÁNDEZ, Historia de la antigua ciudad de Sisapón, hoy Almadén del Azogue, Madrid, 1900 , pp. 259-268; B. CASADO QUINTANILLA, Corona de Castilla: Documentos de la Orden de Calatrava, $\mathrm{n}^{\circ} 13,19,20,25,26$ y 34.

${ }^{7}$ E. RodrígueZ-PICAVEa Matilla, Prosopografía de la Orden de Calatrava en Castilla. La primera mitad del siglo XV, "Meridies. Revista de Historia Medieval", VII (2005), pp. 201-244. 


\section{LOS LINAJES INTRODUCIDOS EN LA ORDEN DE CALATRAVA}

La mayor parte de los caballeros calatravos eran los únicos representantes de su linaje introducidos en la orden o bien pertenecían a un linaje que no puede ser identificado a través de la documentación. En cambio, algo más de la cuarta parte de los freires del brazo secular de la orden procedían de linajes con dos o más representantes en la institución cisterciense ${ }^{8}$. Entre estos linajes destaca de forma sobresaliente sobre los demás el linaje Guzmán, que pudo contar en el período estudiado con un mínimo de 16 caballeros calatravos, repartidos entre, al menos, dos ramas del linaje. El predominio del linaje Guzmán se convierte en abrumador si se tiene en cuenta que tales cifras corresponden únicamente al período comprendido entre 1385 y 1450 , ya que antes del acceso al maestrazgo de Gonzalo Núñez de Guzmán (1385-1404) la presencia de esta familia en la orden de Calatrava era nula.

Los Guzmán introducidos en la orden proceden fundamentalmente de dos ramas. En primer lugar de la línea principal del linaje Guzmán, la de los señores de Guzmán, Roa, Gumiel del Mercado, Abiados y Valle de Boñar, que habían heredado los tres primeros señoríos al extinguirse la rama troncal sin sucesión agnaticia y habían adquirido los dos últimos mediante enlace matrimonial con el linaje Cifuentes. A esta línea principal pertenecían probablemente los maestres Gonzalo Núñez de Guzmán y Luis González de Guzmán y los dos claveros con idéntico antropónimo, patronímico y cognomen, Ramiro Núñez de Guzmán. De esta línea familiar descenderían lógicamente los hijos del maestre González de Guzmán, dos de los cuales pudieron llegar a ocupar encomiendas calatravas antes y después de la muerte de su padre 9 . De tal suerte que Pedro de Guzmán fue sucesivamente comendador Fuente del Emperador ${ }^{10}$ y de Almodóvar ${ }^{11}$ y su hermano Fernando de Guzmán quizás ${ }^{12}$ fue comendador de Maqueda ${ }^{13}$. También desciende de esta línea el freire Luis de Guzmán, nieto del maestre Luis González de Guzmán, ya que era vástago de su hija Inés de Guzmán y de Gil

${ }^{8}$ Es importante subrayar las dificultades que el investigador se encuentra al intentar vincular a la mayoría de los freires calatravos con un linaje determinado. Por otra parte tampoco estamos en condiciones de asegurar que todos los caballeros que llevan el mismo apellido pertenezcan a la misma familia. Por ese motivo, conviene aclarar que utilizamos el sustantivo linaje en su acepción más amplia, comprendiendo así al conjunto de descendientes de un mismo antepasado con afectos e intereses comunes. Vid. R. SÁNCHEZ SAUS, Caballería y linaje en la Sevilla medieval, Cádiz, 1989, p. 39.

${ }^{9}$ E. RodRÍGUEZ-PICAVEA MATILLA, Linaje y poder en la Castilla Trastámara. El ejemplo de la Orden de Calatrava, "Anuario de Estudios Medievales", 35/1 (2005), 91-130, pp. 102-110.

${ }^{10} \mathrm{AHN}, \mathrm{OO} . \mathrm{MM}$., sign. 1348 c, Registro de Escrituras de la Orden de Calatrava, VIII, fols. 66-73; Real Academia de la Historia, Colección Salazar, I-38, fols. 74-86.

${ }^{11}$ AHN, OO. MM., Calatrava carp. 467, $\mathrm{n}^{\circ}$ 321bis y carp. 468, $\mathrm{n}^{\circ}$ 326; B. CASADO QuintanILLA, Corona de Castilla: Documentos de la Orden de Calatrava, no 1, 12, 19 y 20.

${ }^{12} \mathrm{La}$ duda procede de la existencia de dos personajes del mismo nombre y cognomen. Fernando de Guzmán, hijos respectivamente del maestre Luis González de Guzmán y el comendador mayor Juan Ramírez de Guzmán.

${ }^{13}$ AHN, OO. MM., Calatrava, carp. 467, no 313 bis. 
González Dávila, vecino de Ávila, señor del Puente del Congosto y Cespedosa $^{14}$, maestresala de Juan II y alcaide de Burgos ${ }^{15}$. Luis de Guzmán fue comendador de Aceca entre la década de $1440^{16}$ y la década de $1480^{17}$.

En segundo lugar, otros Guzmanes calatravos pertenecen a una rama colateral del linaje, la que procede de Fernán Gómez de Guzmán o de Toledo, camarero mayor de Fernando IV, que cuenta con ascendencia mozárabe. Su hijo Pedro Suárez de Toledo, camarero mayor y mayordomo de Pedro I volvió a entroncar con la línea principal del linaje al contraer matrimonio con María Ramírez de Guzmán, hija del señor de Guzmán Juan Ramírez de Guzmán. El nieto de este matrimonio fue el comendador mayor Juan Ramírez de Guzmán, que era también sobrino segundo del maestre don Gonzalo y primo segundo del maestre don Luis. Naturalmente, los hijos del comendador mayor calatravo proceden de esta rama toledana del linaje ${ }^{18}$. Se trata del también comendador mayor de Calatrava, Fernán Gómez de Guzmán ${ }^{19}$; de Diego de Guzmán, comendador de Zorita ${ }^{20}$ desde la década de 1430; y de Fernando de Guzmán, que desempeñó según $\operatorname{Rades}^{21}$ el cargo de comendador de Talavera y Plasencia ${ }^{22}$.

${ }^{14}$ J.P. MolÉNAT, Les tolédans dans les ordres militaires, du XIIe au XVe siècle, As Ordens Militares e de Cavalaria na Construção do Mundo Ocidental. "Actas do IV Encontro sobre Ordens Militares", Lisboa, 2005, 261-277, p. 275.

${ }^{15}$ J. DE SALAZAR Y ACHA, La Casa del Rey de Castilla y León en la Edad Media, Madrid, 2000, pp. 513-514.

${ }^{16}$ AHN, OO. MM., Calatrava, carp. 468, no 239. Publ. Casado Quintanilla, Corona de Castilla: Documentos de la Orden de Calatrava, $\mathrm{n}^{\mathrm{o}} \mathrm{i}$.

${ }^{17}$ MolÉNAT, Les tolédans dans les ordres militaires, du XIIe au XVe siècle, p. 275.

${ }^{18}$ R. SÁNCHEZ SAUS, Caballería y linaje en la Sevilla medieval, p. 242; J.P. MOLÉNAT, Campagnes et monts de Tolède du XIIe au XVe siècle, Madrid, 1997, pp. 171-172, 338-339 y 369; MOLENAT, Les tolédans dans les ordres militaires, du XIIe au XVe siècle, pp. 261-277; E. RoDRíGUEZ-PICAVEA MATILLA, Prosopografía de la Orden de Calatrava en Castilla. La primera mitad del siglo XV, pp. 218-219 y 235-236.

${ }^{19}$ E. CABRERA y A. MOROS, Fuenteovejuna. La violencia antiseñorial en el siglo XV, Barcelona, 1991, pp. 107-115; M.M. LóPEZ CASAS, Fernán Gómez de Guzmán: el envés histórico de la figura del comendador de Fuenteovejuna, en M. D. Burdeus, E. Real y J. M. Verdegal (eds.), Las Ordenes Militares: realidad e imaginario, Castellón, 2000 , 469-480; E. RODRIGUEZ-PICAVEA MATILLA, Prosopografía de la Orden de Calatrava en Castilla. La primera mitad del siglo XV, pp. 218-219.

${ }^{20}$ AHN, OO. MM., Calatrava, carp. 467, $\mathrm{n}^{\circ} 313$ bis.

${ }^{21} \mathrm{~F}$. de RADES Y ANDRADA, Chronica de las Tres Ordenes y Cauallerias de Sanctiago, Calatraua y Alcantara, Toledo, 1572 (ed. facs. Barcelona, 1980 y Valencia, 1994), Chronica de Calatraua, fol. 78r. El problema de la identificación entre Fernando de Guzmán, comendador de Talavera y las Casas de Plasencia, con el comenḍador mayor Fernán Gómez de Guzmán no está aclarado. E. CABRERA y A. MOROS (Fuenteovejuna, pp. 108-110) defienden que se trata de la misma persona. Rades, en cambio, no identifica al comendador mayor Fernán Gomez de Guzmán con el hijo de Juan Ramírez de Guzmán. Recientemente otra autora ha apuntado la posibilidad de que el comendador mayor que murió en Fuenteovejuna podría ser hijo ilegítimo de Juan Ramírez de Guzmán, al tiempo que plantea que el comendador Fernando de Guzman fuera hijo de Fernán Pérez de Guzmán. Vid. LóPEZ CASAS, Fernán Gómez de Guzmán: el envés histórico de la figura del comendador de Fuenteovejuna, p. 470. En cualquier caso contamos con documentacion que corrobora que Fernán Gómez de Guzmán era hermano de Juan de Guzmán, el hijo primogénito de Juan Ramírez de Guzmán, que se convirtió en señor de Teba y Ardales. Vid. Real Academia de la Historia, Colección Salazar, M-22, fol. 122; M-25, fol. 166; M-104, fol. 154; M-130, fols. $36 \mathrm{v}-37 \mathrm{v}$.

${ }^{22}$ Es posible que antes fuera comendador de Maqueda. La duda, a la que ya hemos aludido, deriva de su posible confusión con el hijo del maestre Luis González de Guzmán. 
La mayor parte de miembros del linaje debieron de estar vinculados, de una u otra forma a estas dos ramas. Sin embargo, los datos que tenemos respecto a otros miembros no permiten constatar su filiación. Lógicamente existen más probabilidades de que pertenecieran a las dos ramas anteriormente citadas, pero tampoco se puede descartar su procedencia de las diversas ramas andaluzas de los Guzmán o de otras ramas toledanas. Así, por ejemplo, no conocemos la filiación exacta de Diego de Guzmán, comendador de Sabiote en las décadas de $1420^{23}$ y $1430^{24}$, ni tampoco de Pedro de Guzmán, que estuvo al frente de la encomienda de Moratalaz entre las décadas de 1440 y $1460^{25}$.

El siguiente de los linajes en importancia cuantitativa fue el de los Padilla, con cinco caballeros calatravos documentados entre 1350 y 1450 . La incidencia cualitativa del linaje fue aún mayor si tenemos en cuenta que dos de esos freires fueron maestres y un tercero, García López de Padilla, fue clavero y se convertiría posteriormente en el último maestre calatravo. Entre los cinco Padillas documentados cabe distinguir a Diego García de Padilla, perteneciente a una rama colateral, de los otros cuatro, que en principio proceden de la rama troncal. En efecto, el maestre Diego García de Padilla (1354-1368) pertenecía a una rama colateral del linaje Padilla, la de los señores de Villagera. Era hijo de Juan García de Padilla, señor de Villagera, y María Gómez de Finestrosa. De este matrimonio nacieron, además del citado maestre calatravo, María Díaz de Padilla, favorita de Pedro I de Castilla, y Juan García de Padilla, teórico maestre de Santiago, impuesto por el monarca ${ }^{26}$. El ascenso de los hermanos Padilla a los maestrazgos de las dos órdenes militares hispánicas más importantes fue posible gracias a la privilegiada posición que ocupaba su hermana. En el contexto de la guerra civil castellana, Diego García de Padilla se pasó al bando trastamarista y como consecuencia de ello, tras la batalla de Nájera, Pedro I le envió prisionero al castillo de Alcalá de Guadaira, donde murió en $1368^{27}$.

Los otros cuatro Padillas se documentan ya en el período comprendido entre 1428 y 1450 . De tal suerte que la ausencia de miembros de esta familia en el organigrama de la orden se prolongó durante más de medio siglo. Las nuevos Padillas se introducen en la orden en el segundo cuarto del siglo XV. El primero de ellos fue Fernando de Padilla, sucesivamente comendador de

${ }^{23} \mathrm{AHN}$, OO. MM., Calatrava, carp. 433 , no 255 y 256 ; Real Academia de la Historia, Colección Salazar, sign. M-5, fol. 279; sign. M-9, fols. 281-292.

${ }^{24}$ AHN, OO. MM., Calatrava, carp. 467, $\mathrm{n}^{\circ} 313$ bis.

${ }^{25}$ AHN, OO. MM., Calatrava, carp. 467 no ${ }^{\circ}$ 321bis; RADES Y ANDRADA, Chronica de Calatrava, fol. $78 \mathrm{r}$; AHN', Nobleza, Osuna, C. $2, n^{\circ} 1$; AHN, OO. MM.. Calatrava, carp. 469 $n^{0}$ 352: CASADO QuINTANILla, Corona de Castilla: Documentos de la Orden de Calatrava, $\mathrm{n}^{\mathrm{d}}$ 19 y 20 .

${ }^{26}$ E. RodríGuez-PiCAVEa MATILla, Linaje y poder en la Castilla Trastámara. El ejemplo de la Orden de Calatrava, pp. 95-96.

${ }^{27} \mathrm{~L}$. V. DíAZ MARTín, Los maestres de las Órdenes Militares en el reinado de Pedro I de Castilla, "Hispania", XL (1978), 285-356, pp. 303-329. 
Mudela $^{28}$, comendador de Aceca ${ }^{29}$, clavero de Calatrava y lugarteniente del maestre en el Campo de Calatrava ${ }^{30}$ y maestre electo en 1443 , cuando murió defendiendo la fortaleza de Calatrava la Nueva como consecuencia de los daños accidentales que le causó uno de los defensores de la plaza. Era hijo de Pedro López de Padilla, señor de Calatañazor y Coruña del Conde, y de Leonor Sarmiento, hija de Pedro Ruiz Sarmiento, señor de Salinas y mariscal de Castilla, y pertenecía, en consecuencia, al tronco principal del linaje. Otro hijo de este matrimonio, García López de Padilla, fue clavero de Calatrava $(1445-1482)^{31}$ y último maestre de la orden $(1482-1489)^{32}$.

De los restantes linajes introducidos en la Orden de Calatrava durante la primera mitad del siglo XV, el de mayor relevancia es el de los Carrillo, que contó al menos con cuatro miembros. Uno de ellos, Lope Carrillo, que previamente había ocupado la encomienda de $\mathrm{Caracuel}^{33}$, llegó a ser comendador mayor ${ }^{34}$ durante la primera parte del maestrazgo de Luis González de Guzmán (1414-1443). A principios del siglo XV, otro de sus parientes, Alonso Carrillo, hijo bastardo del señor de Mondéjar Juan Carrillo, administraba la importante encomienda de Maqueda ${ }^{35}$. Un hermano del citado señor de Mondéjar, Gonzalo Carrillo, fue comendador calatravo de Guadalerza durante el maestrazgo de Pedro Muñiz de Godoy $(1371-1384)^{36}$. Más adelante, entre 1434 y 1469, Pedro Carrillo fue sucesivamente comendador de Moratalaz ${ }^{37}$ y de Piedrabuena ${ }^{38}$.

Con cuatro representantes, todos ellos de la primera mitad del siglo $\mathrm{XV}$, aparece también documentado el linaje Morales, aunque no podemos

${ }^{28} \mathrm{AHN}$, OO. MM., Calatrava, carp. 433, $\mathrm{n}^{\mathrm{o}} 255$ y 256; Real Academia de la Historia, Colección Salazar, sign. M-5, fol. 279; sign. M-9, fols. 281-292.

${ }^{29}$ Real Academia de la Historia, Colección Salazar, sign. M-8, fols. 274v-278r y sign. M130 , fols. 61v-63v; AHN, OO. MM., Calatrava, carp. $467, \mathrm{n}^{\circ} 313$ bis.

${ }^{30}$ I.J. de ORTEGA Y COTES, J.F. ÁlVAREZ DE BAQUEDANO y P. de ORTEGA ZÚÑIGA Y ARANDA, Bullarium Ordinis Militiae de Calatrava, Madrid, 1761 (ed. facs. Barcelona, 1981), pp. 270-272.

${ }^{31}$ AHN, OO. MM., Calatrava, carp. 468, $\mathrm{n}^{\circ}$ 239; RADES Y ANDRADA, Chronica de Calatrava, fol. 78r.; CASẢDO QUINTANILLA, Corona de Castilla: Documentos de la Orden de Calatrava, $\mathrm{n}^{\circ} 1,4,19,20,25$ y 26.

${ }^{32}$ RADES Y ANDRADA, Chronica de Calatrava, fol. 81v; CASADO QuINTANILla, Corona de Castilla: Documentos de la Orden de Calatrava, $n^{\circ}$ 31-34; ORTEGA Y COTES, ALVAREZ DE BAQUEDANO Y ORTEGA ZÚNIGA Y ARANDA, Bullarium Ordinis Militiae de Calatrava, p. 290; E. SOLANO, La Orden de Calatrava en el siglo XV. Los señoríos castellanos de la Orden al fin de la Edad'Media, Sevilla, 1978, pp. 117-122; Lorenzo GALÍnDEZ CARVAJAL Anales breves del reinado de los Reyes Católicos, Biblioteca de Autores Españoles, tomo LXX, Madrid, 1953, 533 565, p. 545.

${ }^{33}$ AHN, OO. MM., Calatrava, carp. 466, no 274 y 275; ORTEGA Y COTES, ÁlvAREZ DE BAQUEDANO Y ORTEGA ŻÚNIGA Y ARANDA, Bullarium Ordinis Militiae de Calatrava, pp. 224227; AHN, OO. MM., Calatrava, carp. 466, $\mathrm{n}^{\circ} 284$.

${ }^{34} \mathrm{AHN}$, OO. MM., Calatrava, carp. 467, n⿳0 297; Real Academia de la Historia, Colección Salazar, sign. M-9, fols. 281-292.

${ }^{35}$ RADES Y ANDRADA, Chronica de Calatrava, fol. $67 \mathrm{v}$.

${ }^{36}$ RADES Y ANDRADA, Chronica de Calatrava, fol. 62v.

${ }^{37}$ AHN, OO. MM., Calatrava, carp. 467, $\mathrm{n}^{0} 313$ bis y 321 bis.

${ }^{38}$ AHN, OO. MM., Calatrava, carp. 468, no 326 y 239; CASADO Quintanilla, Corona de Castilla: Documentos de la Orden de Calatrava, $\mathrm{n}^{\mathrm{o}} 1,19,25 \mathrm{y} 26$; AHN, OÖ. MM., Calatrava, carp. $469, \mathrm{n}^{\mathrm{O}} 358$. 
asegurar que todos los freires pertenezcan a la misma rama. Entre todos los caballeros calatravos de esta familia, sobresale la figura de Lope de Morales, que durante las décadas de 1430 y 1440 ocupó sucesivamente las encomiendas de Víboras ${ }^{39}$, Bexis $^{40}$ y la encomienda mayor de Alcañiz ${ }^{41}$. En las décadas de 1420 y 1430, Ramiro de Morales fue comendador de Ballesteros ${ }^{42}$. Además, Alfonso González de Morales ${ }^{43}$ y Gonzalo de Morales ${ }^{44}$ ocuparon sucesivamente la encomienda de Torroba. A partir de 1433 frey Gonzalo sustituyó la citada encomienda por la más valiosa de Puertollano ${ }^{45}$.

Entre los linajes con tres representantes calatravos sobresalen el linaje Sandoval, que contó con Gutierre Díaz de Sandoval, comendador mayor de Calatrava en $1382^{46}$, y el linaje Godoy, al que pertenecía Pedro Muñiz de Godoy, comendador de Caracuel y maestre de Calatrava (1371-1384) ${ }^{47}$. Otros linajes que cuentan con tres caballeros calatravos en el período estudiado son: Valenzuela, Torres, Figueroa, Venegas y Beteta.

Por su parte, de los linajes que contaron con dos miembros en el período analizado destaca sobre todos ellos el caso del linaje Girón, cuya incidencia cualitativa es más importante que la de la mayoría de los linajes mencionados anteriormente ${ }^{48}$. La primera aparición de un miembro del linaje Girón en la orden de Calatrava se remonta a mediados del siglo XIV, cuando Pedro Girón ocupaba la encomienda de la Peña de Martos. Posteriormente, en el contexto de la guerra civil castellana, este personaje intentó sin éxito alcanzar el maestrazgo calatravo ${ }^{49}$. Sin embargo, no volvemos a encontrar un nuevo miembro del linaje entre los calatravos hasta la elección como maestre de Pedro Girón en 1445. El comendador Girón descendía por línea agnaticia del tronco principal del linaje, el que procedía de Rodrigo González, mayordomo de Alonso VIII, y de Gonzalo Ruiz, maestre de la orden de Santiago fallecido en 1280. En cambio el maestre Girón estaba emparentado

\footnotetext{
${ }^{39} \mathrm{AHN}$, OO. MM., Calatrava, carp. 467, no 313 bis.

${ }^{40}$ OrTEGA Y COTES, ÁlvAREZ DE BAQUEDANO Y ORTEGA ZÚÑIGA Y ARANDA, Bullarium Ordinis Militiae de Calatrava, pp. 250-251.

${ }^{41}$ AHN, OO. MM. Calatrava, carp. 467, no 321bis; S. VIDIELLA, Contribución al catálogo de comendadores de Alcañiz. Orden de Calatrava. Manuscrito inédito, Teruel, 1997, pp. 163176.

${ }^{42}$ AHN, OO. MM., Calatrava, carp. 433 no 255 y 256; Real Academia de la Historia, Colección Salazar, sign. M-5, fol. 279; sign. M-8, fols. 274v-278r; sign. M-9, fols. 281-292; AHN, OO. MM., Calatrava, carp. $467, \mathrm{n}^{8} 313$ bis. y $20 \mathrm{v}$.

${ }^{43}$ AHN, OO. MM., Calatrava, carp. 467, n 297; AHN, OO. MM., sign. 1412c, fols. 13r

${ }^{44}$ AHN, OO. MM., Calatrava, carp. 466, no 284; RADES y ANDRADA, Chronica de Calatrava, fol. 70v; AHN, OO. MM , Calatrava, carp. 433, $\mathrm{n}^{\mathrm{O}} 255$ y 256 ; Real Academia de la Historia, Colección Salazar, sign. M-5, fol. 279; sign. M-9, fols. 281-292.

${ }^{45} \mathrm{AHN}, \mathrm{OO}$. MM., sign. 1348 c, Registro de Escrituras de la Orden de Calatrava, VIII, fols. 66-73; AHN, OO. MM., Calatrava, carp. 467, n ${ }^{\circ} 313$ bis y 321 bis.

${ }^{46}$ OrTEga y COTES, Álvarez de BAQUEDANO y ORTEGA ZÚÑIGA Y ARANDA, Bullarium Ordinis Militiae de Calatrava, pp. 216-218.

${ }^{47}$ RADES Y ANDRADA, Chronica de Calatrava, fols. 58v-62r.

${ }^{48}$ Sobre el tema vid. E. RodRíGUEZ-PICAVEA MATILla, Linaje y poder en la Castilla Trastámara. El ejemplo de la Orden de Calatrava, pp. 110-116.

${ }^{49}$ RADES Y ANDRADA, Chronica de Calatraua, fol. 60r.
} 
por vía cognaticia con esta línea principal de la familia ${ }^{50}$, aunque los Girones del siglo XV son en realidad miembros del linaje Acuña, ya que descendían por línea agnaticia de Martín Vázquez de Acuña, uno de los nobles portugueses emigrados a Castilla a finales del siglo $\mathrm{XIV}^{51}$.

El Pedro Girón que accedió al maestrazgo era hijo de Alonso Téllez Girón, señor de Belmonte y Frechoso, y nieto de Teresa Téllez Girón, última representante del tronco principal de este linaje ${ }^{52}$. Su decisión de utilizar el apellido Girón, relegando así su pertenencia al linaje Acuña, implica un deseo de castellanización absoluta de su linaje y una reivindicación de su procedencia de una de las grandes familias nobiliarias de Castilla.

Entre los restantes linajes de la orden con dos miembros importa destacar el caso de los Villalobos ${ }^{53}$, que contaron entre los caballeros calatravos con Andrés Gil Villalobos, obrero de Calatrava durante el maestrazgo de Diego García de Padilla ${ }^{54}$, y con Fernando Rodríguez Villalobos, clavero de la orden de Calatrava ${ }^{55}$ y maestre de la orden de Alcántara (1394-1406) ${ }^{56}$. Por su parte, los Cárdenas tenían como representantes al clavero García López de Cárdenas $(1382)^{57}$ y a Pedro Muñiz de Cárdenas, que entre 1396 y 1406 fue comendador, primero de Mudela ${ }^{58}$ y

${ }^{50} \mathrm{~S}$. DE MOXÓ ORTIZ DE VILLAJOS, De la nobleza vieja a la nobleza nueva. La transformación nobiliaria castellana en la baja Edad Media, "Cuadernos de Historia. Anexos de la Revista Hispania", 3 (1969), 1-210, pp. 73 y 76-77.

${ }^{51} \mathrm{E}_{\text {; }}$ MITRE, La emigración de nobles portugueses a Castilla a fines del siglo XIV, "Hispania", 104 (1966), 513-526, p. 521.

${ }^{52}$ Sobre la figura de Pedro Girón y su linaje vid. F. UHAGÓN, Órdenes militares. Discursos leídos ante la Real Academia de la Historia, Madrid, 1898, pp. 12-34; J., O'CALLAGHAN, Don Pedro Giron, Master of the Order of Calatrava, 1445-1446, "Hispania", 21 (1961), 342-392 (reimpresión en su libro The Spanish Military Order of Calatrava and its Affiliates, VIII); M ${ }^{\mathrm{a}} \mathrm{I}$. DEL VAL VALDIVIESO, Relaciones de Don Pedro Giron, maestre de Calatrava, con el rey Don Enrique IV, en VII Centenario del infante don Fernando de la Cerda, Ciudad Real, 1976, 159170; 1. ATIENZA HERNÁNDEZ, Aristocracia, poder y riqueza en la España moderna. La Casa de Osuna, siglos XV-XIX, Madrid, 1987; A.VINA BRITT, Don Pedro Girón, maestre de Calatrava, y los orígenes de la Casa de Osuna, Tesis Doctoral, Universidad de Sevilla, 1986 (microfichas, Barcelona, 1988); F.J. A GUADO GONZÁLEZ, El ascenso de un linaje castellano en la segunda mitad del siglo XV: los Téllez Girón, condes de Urueña (el origen del señorio de Osuna), 2 vols., Madrid 1991; E. CABRERA y A. MOROS, Fuenteovejuna, pp. 79-106; A. FRANCO SILVA, Don Pedro Girón, fundador de la Casa de Osuna (1423-1466), Osuna entre los tiempos medievales y modernos (Siglos XIII-XVIII), Sevilla, 1995, 63-93 (reeditado en su libro Señores y señoríos, Jaén, 1997, 217-260).

53 Importante linaje nobiliario, cuya rama troncal se extinguió al inicio de la etapa Trastámara. Vid. S. DE MOXÓ, De la nobleza vieja a la nobleza nueva, pp. 101-105.

${ }^{54}$ RADES Y ANDRADA, Chronica de Calatrava, fol. 52r.

${ }^{55}$ Documentado como tal entre junio de 1392 y diciembre de 1393. Vid. AHN, OO. MM., sign. $1348 \mathrm{c}$, Registro de Escrituras de la Orden de Calatrava, VIII fol. 22 (publ. İ.J. ORTEGA Y COTES, F. ALVAREZ DE BAQUEDANO Y P. DE ORTEGA ZÚNIGA Y ÂRANDA, Bullarium Ordinis Militiae de Calatrava, pp. 223-224); AHN, OO. MM., carp. 466, no 274 y 275; Real Academia de la Historia, Coleccion Salazar, sign. M-130, fols. $45-47$ y $49 \mathrm{v}-52 \mathrm{r}$.

${ }^{56} \mathrm{~L}$. CORRAL VAL, Los monjes soldados de la Orden de Alcántara en la Edad Media. Su organización institucional y vida religiosa, Madrid, 1999, pp. 187 y 367-369.

${ }^{57}$ ORTEGA Y COTES, ÁLVAREZ DE BAQUEDANO y ORTEGA ZÚÑIIGA Y ARANDA, Bullarium

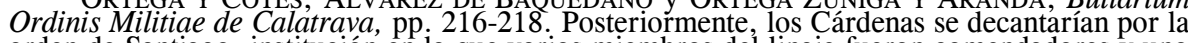
orden de Santiago, institución en la que varios miembros del linaje fueron comendadores y uno de ellos, Alonso de Cárdenas, llegó a ocupar el maestrazgo (1477-1493).

${ }^{58}$ AHN, OO. MM.,, Calatrava, carp. 466, no 274 y 275; Real Academia de la Historia, Colección Salazar, sign. M-130, fols. 42-44. 
después de Sabiote ${ }^{59}$, y lugarteniente del maestre en el Campo de Campo de Calatrava $^{60}(1392-1406)$. Otros linajes que se documentan con dos miembros son Angulo, Aza, Ramírez de Sevilla, Ribera, Roelas, Sotomayor y Valdelomar.

Por último, muchos linajes cuentan en este período con un solo representante entre las dignidades calatravas, aunque podemos encontrar otros miembros de sus familias en etapas inmediatamente anteriores o posteriores a la que estamos analizando. En cualquier caso, la investigación se ve limitada por la ausencia de filiaciones completas y seguras para todos los freires calatravos. Entre estos caballeros cabe reseñar en primer lugar a los maestres Martín López de Córdoba (1367-1371) y Pedro Álvarez de Pereira (13841385), además del aspirante a comendador mayor Gutierre Téllez de Meneses, que militó en el partido del antimaestre Pedro Estébanez Carpenteiro ${ }^{61}$. Por lo que se refiere a los restantes caballeros sobresale el nombre de Diego Ponce de León, comendador de Montanchuelos ${ }^{62}$ (1443-1445) y posteriormente de Castilserás ${ }^{63}$. Era uno de los numerosos hijos naturales de Juan Ponce de León, II conde de Arcos, que no tuvo descendencia legítima. En consecuencia, el comendador calatravo era también hermano de padre de Rodrigo Ponce de León, I marqués y duque de Cádiz y III conde de $\operatorname{Arcos}^{64}$.

\section{SOCIOLOGÍA DE LOS LINAJES CALATRAVOS}

Sólo una parte reducida de los linajes introducidos en la orden de Calatrava procedía de la alta nobleza castellana ${ }^{65}$. Se trata de los linajes Aza,

${ }^{59} \mathrm{AHN}$, OO. MM.,, Calatrava, carp. 466, $\mathrm{n}^{\mathrm{o}} 284$.

${ }^{60}$ Publ. ORTEGA Y COTES, ÁlvAREZ DE BAQUEDANO Y ORTEGA ZÚÑIGA Y ARANDA, Bullarium Ordinis Militiae de Calatrava, pp. 224-227.

${ }^{61}$ RADES Y ANDRADA, Chronica de Calatraua, fols. 56, 59, 62v-63r; Chronica de Alcantara, fols. $34 \mathrm{r}-34 \mathrm{v}$.

${ }^{62} \mathrm{AHN}$, OO. MM., Calatrava, carp. 467, no 321bis; RADES Y ANDRADA, Chronica de Calatrava, fol. $78 \mathrm{r}$.

${ }^{63}$ Casado Quintanilla, Corona de Castilla: Documentos de la Orden de Calatrava, $\mathrm{n}^{\mathrm{o}} 19$, $20,21,25$ y 26 .

${ }^{64}$ SÁNCHEZ SAUS, Caballería y linaje en la Sevilla medieval, pp. 349-353.

${ }^{65}$ En relación a la extensa bibliografía sobre la nobleza castellana en la Baja Edad Media remitimos a los balances historiográficos, que incluyen amplios repertorios, de M.C. QUINTANILLA RASO, Nobleza y señoríos en Castilla durante la Baja Edad Media. Aportaciones de la historiografía reciente, "Anuario de Estudios Medievales", 14 (1984) 613-639; Historiografía de una élite de poder: la nobleza castellana bajomedieval, "Hispania", 175 (1990) 719-736; y El protagonismo nobiliario en la Castilla bajomedieval. Una revisión historiográfica (1984-1997)

"Medievalismo. Boletín de la Sociedad Española de Estudios Medievales", 7 (1997) 187-234"

Con posterioridad a esta última fecha, pueden verse, entre otras, las obras de M. CABRERA SÁNCHEZ, Nobleza, oligarquía y poder en Córdoba al final de la Édad Media, Córdoba, 1998 V.M. GIBELLO BRAVO, La imagen de la nobleza castellana en la Baja Edad'Media, Badajoz, 1999: A.B. SÁNCHEZ PRIETO, La casa de Mendoza hasta el tercer duque del Infantado (13501531): el ejercicio y alcance del poder señorial en la Castilla bajomedieval, Madrid, 2001; y el volumen colectivo La nobleza peninsular en la Edad Media. VI Congreso de Estudios Medievales, Fundación Sánchez Albornoz, Avila, 1999. Con anterioridad, es interesante recordar, por su carácter más general, la visión ofrecida por I. BECEIRO PITA y R. CóRDOBA DE LA LLAVE, Parentesco, poder y mentalidad. La nobleza castellana. Siglos XII-XV, Madrid, 1990. Muy recientemente se ha publicado la obra colectiva dirigida por M.C. QUINTANILLA RASO, Títulos, 
Coronel $^{66}$, Girón, Guzmán, Meneses, Ponce de León y Villalobos ${ }^{67}$. A ellos cabe unir otras familias que, en el momento de introducirse en la institución cisterciense, podían considerarse de la nobleza media ${ }^{68}$ como es el caso de los linajes Cárdenas, Carrillo, Padilla, Sandoval y Venegas ${ }^{69}$ en el tercer cuarto del siglo XIV. Pues bien, todos estos linajes, con la excepción de Aza, Coronel, Ponce de León y Venegas, que ocuparon sólo encomiendas calatravas, fueron los que fundamentalmente accedieron al triunvirato de poder en la orden, representado por el maestrazgo, la encomienda mayor y la clavería. Fuera de estas familias de la alta y media nobleza encontramos contadas excepciones de miembros de la baja nobleza ocupando el triunvirato calatravo. Se trata de los maestres Martín López de Córdoba y Pedro Muñiz de Godoy, que a mediados de la decimocuarta centuria podían considerarse como procedentes de familias de la baja nobleza. En el caso de los maestres, el ascenso hasta la más alta magistratura de la orden se explica en el convulso contexto de la guerra civil castellana.

Una parte importante de los restantes linajes calatravos conocidos pertenecían probablemente a la oligarquía urbana de Toledo $^{70}$ (Barroso, Gaitán

grandes del reino y grandeza en la sociedad política. Los fundamentos en la Castilla medieval, Madrid, 2006.

${ }^{66}$ M.C. Gerbet, Las noblezas españolas en la Edad Media. Siglos XI-XV, Madrid, 1997, pp. 133-136.

${ }^{67}$ S. DE Moxó, De la nobleza vieja a la nobleza nueva, p. 27.

${ }^{68}$ Resulta complicada la clasificación de algunos linajes de la nobleza castellana, que en función de determinadas coyunturas pudieron pertenecer al escalón superior, medio o inferior de la aristocracia. Es el caso de los Carrillo, los Padilla y los Sandoval, a los que Carlos Estepa sitúa con acierto, al mediar el siglo XIV, en el grupo de la nobleza regional. Este autor ha realizado una gran aportación y un notable esfuerzo de clasificación de la nobleza de Castilla la Vieja, a distinguir cuatro grupos: la alta nobleza de ricoshombres, la nobleza regional, la nobleza comarcal y la nobleza local. Vid. C. ESTEPA DíEZ, Las behetrías castellanas, 2 vols., Valladolid, 2003 , 1, pp. 271-275, 334-339, 367-371 y 378-404. En todo caso, para el conjunto del reino castellano, nos movemos en el terreno de las aproximaciones, ya que carecemos de un estudio sistemático sobre la posición social de un buen número de familias nobiliarias del siglo XIV.

${ }^{69}$ Sobre los Venegas contamos con la importante aportación que supone la Tesis Doctoral de M. CABRERA SÁNCHEZ, Nobleza, oligarquía y poder en Córdoba al final de la Edad Media, pp. 58-61 y 114-115. La autora sitúa a los Venegas entre los linajes de la alta nobleza cordobesa del siglo XV. Desde nuestra perspectiva del reino castellano en la segunda mitad del siglo XIV momento de la introducción del linaje en la orden de Calatrava, parece más adecuado considerar a la familia al nivel de la nobleza media de Castilla, cuyos representantes contaban también con un señorío rural pero no alcanzaban todavía el nivel de la alta nobleza y menos el de la nobleza titulada. Conviene subrayar que en esa época el pariente mayor del linaje. Egas Venegas, había recibido el señorío de Luque $(c .1372$ ). Todo ello teniendo en cuenta la difícultad que representa realizar precisas clasificaciones para el siglo XIV. En la centuria siguiente una parte importante de los linajes de esta nobleza media ascendió hasta las filas de la alta nobleza. Es el caso también de los Cárdenas, incluidos en el siglo XV en la alta nobleza toledana. Vid. J.P. MOLÉNAT, Campagnes et monts de Tolède du XIle au XVe siècle, $\mathrm{p}$. 354. Naturalmente, el ascenso social de los Carrillo resulta todavía más evidente. Vid. M.C. GERBET, Las noblezas españolas en la Edad Media, p. 166.

${ }^{70}$ Sobre la oligarquía toledana la obra de referencia es la ya citada de J.P. MoLÉNAT, Campagnes et monts de Tolède du XIIe au XVe siècle; a la que cabe sumar otros trabajos anteriores del mismo autor como L'oligarchie municipale de Tolede au XVème siècle, en Tolède et l'expansion urbaine en Espagne (1450-1650), Madrid, 1991, pp. 159-177; y La noblesse tolédane du XVème siècle et ses origines, en Les sociétés urbaines en France méridionale et en Péninsule Ibérique au Moyen Age. "Actes du Colloque de Pau, 21-23 -IX-1988", París, 1991, pp. 203-218. Para el siglo XV es obligada también la consulta de la Tesis Doctoral de J.R. PALENCIA HERREJón, Ciudad y oligarquía de Toledo a fines del Medievo (1422-1522), Universidad Complutense, 1999, edición en CD, Madrid, 2003. 
y Sotomayor $^{71}$ ), Córdoba ${ }^{72}$ (Aguayo, Angulo, Godoy, Valdelomar y Valenzuela), Sevilla ${ }^{73}$ (Ramírez de Sevilla, Ribera y Roelas) y Soria ${ }^{1 / 4}$ (Morales, San Clemente y Santa Cruz). Resulta extraordinariamente significativa la procedencia de una buena parte de los linajes calatravos de estas cuatro ciudades ${ }^{75}$, ya que todas ellas contaron con una encomienda urbana de la milicia cisterciense ${ }^{76}$. Además, el reino de Toledo y la Andalucía Bética eran las regiones donde se situaban la parte fundamental de los señoríos calatravos. Varios de los caballeros de linajes originarios de las ciudades situadas en estas regiones disfrutaron de las encomiendas urbanas de su ciudad de origen o de las encomiendas rurales situadas en su comarca circundante.

Por lo que se refiere al resto de los caballeros calatravos, de linaje desconocido o de familia sin una vinculación geográfica conocida, cabe deducir que no se trata, salvo algunas excepciones, de individuos de la alta nobleza, ni probablemente tampoco de personas procedentes de la nobleza media, ya que en caso contrario lo habitual hubiera sido que hubiera quedado consignado el linaje al que pertenecían ${ }^{77}$. Lo más plausible es que se trate de caballeros hidalgos, como era preceptivo para ingresar en la orden, pero pertenecientes a las oligarquías locales de las ciudades citadas y de otras de similar o menor importancia. De tal suerte que sería de las filas de la baja nobleza de donde mayoritariamente procederían los caballeros de la orden de Calatrava.

${ }^{71}$ La procedencia toledana de los Sotomayor calatravos en RADES Y ANDRADA, Chronica de Calatrava, fol. $62 \mathrm{v}$.

${ }^{72} \mathrm{La}$ referencia imprescindible en el caso de Córdoba se encuentra en el libro ya mencionado de M. CABRERA SÁNCHEZ, Nobleza, oligarquía y poder en Córdoba al final de la Edad Media.

${ }^{73}$ Sobre la aristocracia sevillana bajomedieval el gran especialista es R. SÁNCHEZ SAUS, autor del ya citado Caballería y linaje en la Sevilla medieval; y de Linajes sevillanos medievales, 2 vols., Sevilla, 1990.

${ }^{74}$ Para el caso soriano contamos con los trabajos de M. DiAGo HeRnando, Estructuras familiares de la nobleza urbana en la Castilla bajomedieval: los doce linajes de Soria, "Stvdia Historica. Historia Medieval", 10 (1992), pp. 47-71; y Estructuras de poder en Soria a fines de la Edad Media, Valladolid, 1993; y M. ASENJO GoNZÁlEZ, Espacio y sociedad en la Soria medieval. Siglos XIII-XV, Soria, 1999.

${ }^{75} \mathrm{Se}$ constata la presencia de estos linajes en las cuatro ciudades señaladas, aunque no podemos garantizar en todos los casos que los freires calatravos procedieran de las ciudades donde estaban arraigadas estas familias. Otros linajes resultan de problemática adscripción geográfica. Por ejemplo, los Torres y los Beteta calatravos pudieron proceder de la oligarquía soriana o de la conquense. Sobre esta última vid. J.A. JARA FUENTE, Concejo, poder y élites. La clase dominante de Cuenca en el siglo XV, Madrid, 2000. En el caso de los Beteta se documenta además un Gonzalo de Beteta como regidor de Ciudad Real por lo que los caballeros calatravos también pudieron tener esta procedencia geográfica. Vid. M. DIAGO HERNANDO, Estructuras familiares de la nobleza urbana en la Castilla bajomedieval: los doce linajes de Soria, nota 64. En otros casos, la presencia del mismo apellido en varios concejos castellanos dificulta extraordinariamente cualquier aproximación al origen geográfico de los caballeros calatravos que pertenecen a esas familias.

${ }^{76} \mathrm{La}$ encomienda del Rabal o de San Salvador de Soria se documenta en 1382. Vid. ORTEGA Y COTES, AlvAREZ DE BAQUEDANO y ORTEGA ZÚNIGA Y ARANDA, Bullarium Ordinis Militiae de Calatrava, pp. 216-218.

${ }^{77}$ Pudieron producirse excepciones, pero no parece que fueran muy numerosas. En una época donde el apellido, como expresión de pertenencia a un linaje, era signo de orgullo y prestigio social, debieron ser infrecuentes los casos de individuos de la alta y media nobleza que no lo utilizaran. Por otra parte, es probable que a la propia institución, de la que emanaba la documentación donde se registraban los nombres de los freires, le interesara subrayar la presencia de caballeros pertenecientes a importantes linajes castellanos. 


\section{FAMILIAS NOBILIARIAS CASTELLANAS Y DOMINIO DE LA ORDEN DE CALATRAVA}

Hasta la llegada de los Guzmán a la cúpula de poder de la orden de Calatrava en 1385, no existe un dominio de la orden por una única familia nobiliaria. Antes de esa fecha se produce el reparto de los principales resortes de poder político y económicos de la orden, cuyas consecuencias se prolongan todavía durante los primeros tiempos de la etapa de los Guzmán como dominadores de la institución cisterciense. De tal suerte que, dejando al margen el caso de los maestres Padilla, López de Córdoba y Pereira, el poder se lo repartieron entre los Godoy, Cárdenas, Carrillo, Sandoval y Sotomayor. Así, por ejemplo, los Godoy contaron con Pedro Muñiz de Godoy, comendador de Caracuel y después maestre, y con su hijo Diego Muñiz de Godoy, comendador de Malagón ${ }^{78}$. Los Cárdenas estaban representados por el clavero García López de Cárdenas y por Pedro Muñiz de Cárdenas, comendador de Mudela y Sabiote ${ }^{79}$. Los Carrillo tenían como representantes a Gonzalo Carrillo, comendador de Guadalerza ${ }^{80}$, y sobre todo a Lope Carrillo, comendador de Caracuel y comendador mayor de Calatrava tras el acceso de Luis González de Guzmán al maestrazgo ${ }^{81}$. En el último cuarto del siglo XIV, los Sandoval podían presumir de contar con Gutierre Díaz de Sandoval, comendador mayor de Calatrava, Diego Gómez de Sandoval, comendador de Osuna, y Rodrigo Díaz de Sandoval, alférez calatravo y comendador de Fuente del Emperador ${ }^{82}$. Finalmente, en las décadas de 1370 y 1380, los Sotomayor estaban representados por Pedro Meléndez de Sotomayor, comendador de Malagón, y por García Suárez de Sotomayor, comendador de Toledo y Borox ${ }^{83}$.

Este reparto del poder, que impide constatar un predominio claro de un linaje sobre otro, cambiaría con el acceso de Gonzalo Núñez de Guzmán al maestrazgo en 1385. El linaje Guzmán no tenía ninguna presencia en ese momento. En menos de una década, el maestre consiguió situar a sus familiares al frente de las tres encomiendas más importantes: su hijo Luis González de Guzmán se convirtió en comendador mayor ${ }^{84}$, su sobrino Gonzalo Núñez de Guzmán en comendador de Malagón, primero, y en

\footnotetext{
${ }^{78}$ RADES Y ANDRADA, Chronica de Calatrava, fols. 58v-59r.

${ }^{79}$ OrTEga y COTES, Álvarez dE BAQUEDANO y ORTEGA ZÚÑIGA Y ARANDA, Bullarium Ordinis Militiae de Calatrava, pp. 216-218.

${ }^{80}$ RADES Y ANDRADA, Chronica de Calatrava, fol. 62v.

${ }^{81}$ AHN, OO. MM., Calatrava, carp. 466, no 274 y 275; ORTEGA Y COTES, ÁlvAREZ DE BAQUEDANO Y ORTEGA'ZÚNIGA Y ARANDA, Bullarium Ordinis Militiae de Calatrava, pp. 224227; AHN, OO. MM., Calatrava, carp. 466, n⿳0 284 y 297.

${ }^{82}$ RADES Y ANDRADA, Chronica de Calatrava, fols. 62r y 65r.

${ }^{83}$ RADES Y ANDRADA, Chronica de Calatrava, fol. 62v.

${ }^{84} \mathrm{El} 20$ de junio de 1392 aparece documentado por primera vez como comendador mayor de Calatrava. Vid. AHN OO. MM., sign. 1348 c, Registro de Escrituras de la Orden de Calatrava, VIII, fol. 22. Publ. ORTEGẢ Y COTES, ALVAREZ DE BAQUEDANO Y ORTEGA ZÚNIGA Y ARANDA, Bullarium Ordinis Militiae de Calatrava, pp. 223-224.
} 
clavero, después ${ }^{85}$, y su sobrino segundo Juan Ramírez de Guzmán en comendador de $\operatorname{Otos}^{86}$. Paralelamente otros miembros de esta prolífica familia disfrutaron de importantes encomiendas calatravas: Alfonso Ramírez de Guzmán de la encomienda de Almodóvar ${ }^{87}$ y Álvaro Sánchez de Guzmán sucesivamente de las encomiendas de Villarrubia y Malagón ${ }^{88}$.

El dominio de los Guzmán sobre el triunvirato de poder calatravo se prolongó hasta 1443, con las excepciones del maestre Enrique de Villena (1404-1414) y del comendador mayor Lope Carrillo (1414-1428). Luis González de Guzmán ocupó el maestrazgo, Juan Ramírez de Guzmán la encomienda mayor, al tiempo que conservaba otras encomiendas, incluida la importantísima de $\operatorname{Otos}^{89}$, y un segundo Gonzalo Núñez de Guzmán fue clavero ${ }^{90}$

En la década de 1440 los Guzmán se vieron obligados a compartir ese poder con un linaje que se había vuelto a introducir en la orden, el de los Padilla, que consiguió hacerse con el control de la clavería, e incluso coyunturalmente con el maestrazgo ${ }^{91}$. Los Guzmán lograrían conservar la encomienda mayor y algunas otras encomiendas, pero a cambio debieron renunciar al maestrazgo, que pasó a manos de los Girón, y dejar que la clavería fuera controlada por los Padilla. De tal suerte que la lucha por el poder acaecida en la década de 1440 se cerró con un reparto entre los tres linajes implicados, en el que los Guzmán, teniendo en cuenta la situación de la que partían, fueron los grandes perjudicados ${ }^{92}$.

${ }^{85}$ AHN, OO. MM., Calatrava, carp. 466, ${ }^{\circ} 275$.

${ }^{86} \mathrm{AHN}$, OO. MM., sign. 1348 c, Registro de Escrituras de la Orden de Calatrava, VIII, fol 22. Publ. ORTEGA Y COTES, AlVAREZ DE BAQUEDANO Y ORTEGA ZÚNIGA Y ARANDA, Bullarium Ordinis Militiae de Calatrava, pp. 223-224.

${ }^{87} \mathrm{AHN}$, OO. MM., carp. 466, $\mathrm{n}^{\circ}$ 275; Real Academia de la Historia, Colección Salazar, sign. M-130, fols. 42-44.

${ }^{88} \mathrm{AHN}$, OO. MM., Calatrava, carp. 466, no 274 y 275; Real Academia de la Historia Colección Salazar, sign. M-130 fols. 42-44; ORTEGA Y COTES, ALVAREZ DE BAOUEDANO Y ORTEGA ZUNIIGA Y ARANDA, Bullarium Ordinis Militiae de Calatrava, pp. 224-227; AHN, OO. MM., Calatrava, carp. 466, $\mathrm{n}^{\circ}$ 281; RADES Y ANDRADA, Chronica de Calatrava, fol. 68r.

${ }^{89} \mathrm{AHN}$, OO. MM., Calatrava, carp. 467, $\mathrm{n}^{\circ} 313$ bis.

${ }^{90}$ RADES Y ANDRADA, Chronica de Calatrava, fols. $67 \mathrm{v}$ y $70 \mathrm{v}$. El cronista calatravo distingue a dos Ramiro Núñez de Guzmán que aparecen sucesivamente al frente de la clavería. Del primero, que hace coincidir con el maestrazgo de Gonzalo Núñez de Guzmán, especifica que fue sobrino de este maestre. Del segundo, que ocupó el cargo durante el maestrazgo de Luis González de Guzmán, aclara que fue sobrino de este último y tuvo dos hijas naturales. Esta versión, que no es posible contrastar con otras fuentes, tiene visos de verosimilitud debido al conocimiento que Rades tenía sobre la documentación de su Orden, pero tampoco conviene descartar que se trate en realidad de un único personaje que disfrutó de la clavería durante varias décadas. La documentación manejada no nos permite despejar la duda y en consecuencia tampoco decantarnos plenamente por una de las dos posibilidades.

91 ORTEGA Y COTES, ÁlvAREZ DE BAQUEDANO Y ORTEGA ZÚÑIGA Y ARANDA, Bullarium Ordinis Militiae de Calatrava, pp. 270-272; E. SOLANO La Orden de Calatrava en el siglo XV. Los señoríos castellanos de la Orden al fin de la Edad Media, Sevilla, 1978, pp. 80-82.

${ }^{92} \mathrm{E}$. CABRERA, En torno a una enconada rivalidad por el Maestrazgo de Calatrava durante el siglo XV, "Espacio, Tiempo y Forma. Historia Medieval", 2 (1989), pp. 75-96; E. CABRERA, El acceso a la dignidad de maestre y las divisiones internas de las Ordenes Militares durante el siglo XV, en Las Ordenes Militares en la Península Ibérica, I. Edad Media, R. IZQUIERDO BENITO y F. RUIZ GómEZ (eds.), Cuenca, 2000, pp. 281-306. 


\section{LAS ENCOMIENDAS Y EL REPARTO DEL PATRIMONIO CALATRAVO}

En líneas generales, se puede considerar que el patrimonio calatravo estaba ya consolidado a mediados del siglo XIV. Durante los 100 años siguientes se produjeron algunos reajustes importantes que adoptaron la modalidad de permutas. Sin embargo, no se produjo ni un incremento sustancial, ni una disminución significativa del patrimonio de la orden.

Estos reajustes patrimoniales tienen, con carácter general, como objetivo conseguir propiedades en la Andalucía Bética y Murcia, regiones fronterizas con al-Andalus y únicas que podían justificar la función primitiva de las órdenes militares, a cambio de desprenderse de propiedades calatravas situadas en otras regiones. Con todo, las permutas respondieron también a intereses de los que las realizaban y los maestres respectivos, más que a intereses generales de la orden. Cuatro son las permutas que se constatan en este período:

En 1378, Enrique II de Castilla entregó a la orden de Calatrava Villafranca de Córdoba a cambio de Cogolludo, Loranca y Torralba, situados en la actual provincia de Guadalajara ${ }^{93}$.

En 1428, el rey Juan de Navarra y mosén Francisco Ariño, secretario del rey de Aragón, cedieron a los calatravos El Colmenar (Ávila) y Castil de Castell (Valencia) a cambio de Maella, Favara y Calaceite (Aragón) ${ }^{94}$.

En junio de 1434, el doctor Diego González de Toledo, contador mayor de Juan II de Castilla, dio a la orden la villa murciana de Abanilla a cambio de las propiedades que integraban la encomienda calatrava de Castilla, todas ellas situadas al norte del Sistema Central ${ }^{95}$.

En el mismo año 1434, Álvaro de Luna, condestable de Castilla, entregó a los calatravos Arjona, Arjonilla, La Higuera, Recena, tres cuartas parte de Jimena, 30.000 maravedís por juro de heredad, la renta del almojarifazgo y escribanías públicas de Ciudad Real y «otras cosas» a cambio de Maqueda, San Silvestre y El Colmenar ${ }^{96}$.

Por otra parte, a mediados del siglo XIV, había concluido ya el proceso que condujo al reparto de los bienes calatravos entre la mesa maestral, que por lo que sabemos por cifras posteriores se quedaría aproximadamente con la mitad de las rentas de la orden, y las encomiendas, cuyas rentas supondrían alrededor de la mitad restante ${ }^{97}$.

\footnotetext{
${ }^{93}$ RADES Y ANDRADA, Chronica de Calatrava, fols. 61v-62r.

${ }^{94} \mathrm{AHN}$, OO. MM., Calatrava, carp. 433, $\mathrm{n}^{\mathrm{o}} 255$ y 256; Real Academia de la Historia, Colección Salazar, sign. M-5, fol. 279; sign. M-9, fols. 281-292.

${ }^{95} \mathrm{AHN}$, OO. MM., Calatrava, carp. 467, $\mathrm{n}^{\circ}$ 313bis.

${ }^{96} \mathrm{AHN}$, OO. MM., Calatrava, carp. 467, $\mathrm{n}^{\circ} 314$.

${ }^{97}$ Solano, La Orden de Calatrava en el siglo XV, pp. 305-310.
} 
Durante el período 1350-1450 el número de encomiendas fue incrementándose hasta rondar el medio centenar ${ }^{98}$. El aumento en el número de encomiendas pudo hacerse a costa de la mesa maestral y de la fragmentación de las encomiendas ya existentes. Probablemente se utilizaron las dos modalidades para evitar desequilibrar en exceso hacia una parte la distribución de los recursos de la orden. La cifra es similar a la que conocemos para la segunda mitad del siglo XV, cuando la orden de Calatrava contaba con 50 encomiendas en Castilla, además de las tenencias que disfrutaba el brazo clerical como la encomienda del convento de Calatrava la Nueva, la encomienda de la Sacristanía y los prioratos de Fuencaliente, Zorita, Toledo, Sevilla, Porcuna y Jaén ${ }^{99}$.

En el segundo cuarto del siglo XV se documentan 53 encomiendas diferentes en el reino castellano, al margen de las correspondientes al brazo clerical. Bien es cierto que dos de ellas se extinguirían para siempre en 1434 como consecuencia de sendas permutas. Se trata de las encomiendas de Maqueda y Castilla. Además desaparece la encomienda de La Membrilla, que no volvería a reaparecer ya hasta el siglo XVI. Estas tres variaciones explican esa pequeña diferencia numérica. Las mismas razones justifican también que el mayor número de encomiendas se documente durante el maestrazgo de Luis González de Guzmán (1414-1443) ${ }^{100}$. Fue precisamente durante este maestrazgo cuando se produjeron los más importantes reajustes patrimoniales.

En definitiva, en las décadas centrales del siglo XV se estableció en torno al medio centenar el número de freires caballeros que podrían disfrutar de una encomienda. Sin embargo, se trata de una cifra máxima, ya que en algunas ocasiones se documentan ciertos caballeros calatravos al frente de más de una encomienda. El ejemplo más destacado es el de Juan Ramírez de Guzmán, documentado en 1423 como comendador de Otos, Aceca y las Casas de Toledo; cinco años después era comendador de Otos, Guadalerza, Caracuel, Casas de Toledo y Aceca; y en 1434 figura como comendador mayor y comendador de Otos, Osuna, Corral de Caracuel y Guadalerza ${ }^{101}$.

En contraste, otros freires de la orden quedaban fuera de este reparto $^{102}$. En concreto, y sólo durante el período analizado, se documentan

\footnotetext{
${ }^{98} \mathrm{La}$ evolución puede observarse en el gráfico que figura al final del trabajo. Las cifras que se recogen se refieren solamente a las encomiendas documentadas en cada período. Naturalmente, no se trata de ceifras absolutas, ya que en algunos períodos parece claro que el número de encomiendas existentes era superior al documentado. Por otra parte, no todas las encomiendas que se documentan a lo largo de un período existieron al mismo tiempo. En cualquier caso, las cifras recopiladas sí permiten señalar una tendencia al incremento hasta alcanzar el medio centenar de circunscripciones calatravas a mediados del siglo XV.

${ }^{99}$ Solano, La Orden de Calatrava en el siglo XV, pp. 187-290.

${ }^{100}$ Conviene aclarar que las encomiendas se documentan a lo largo de todos los años de la duración del maestrazgo. Por tanto, no existen todas al mismo tiempo.

${ }^{101}$ Vid. Real Academia de la Historia, Colección Salazar, sign. M-130, fol. 56v-59; AHN, OO. MM., Calatrava, carp. 433, $\mathrm{n}^{\circ} 255$ y 256; Real Academia de la Historia, Colección Salazar, sign. M-5, fol. 279 y sign. M-9, fols. 281-292; AHN, OO. MM., Calatrava, carp. 467, n ${ }^{\circ} 313$ bis.

${ }^{102}$ Sobre el reparto patrimonial entre los comendadores de la orden de Santiago vid. M. RODRÍGUEZ LLOPIS, Poder y parentesco en la nobleza santiaguista del siglo XV, "Noticiario de Historia Agraria”, 12 (1996), 57-90.
} 
hasta 17 caballeros que no aparecen posteriormente ocupando una encomienda. De esta circunstancia cabe deducir que ciertos freires comenzaban y terminaban su carrera en la orden siendo simples caballeros. Los beneficiados por el reparto de recursos de la orden no estaban dispuestos a renunciar a parte de lo que ya tenían en beneficio de otros miembros de la institución.

Cierto es que todas las encomiendas no tenían ni mucho menos el mismo valor económico y sólo algunas permitían disfrutar de un volumen sobresaliente de rentas anuales. Utilizando datos de la segunda mitad del siglo $\mathrm{XV}^{103}$, podemos establecer hasta cinco categorías diferentes de encomiendas en función de sus rentas: maravedís)

1) encomiendas de carácter extraordinario (800.000-1.200.000

2) encomiendas grandes (250.000-600.000 maravedís)

$3)$ encomiendas medianas (150.000-250.000 maravedís)

4) encomiendas pequeñas (75.000-150.000 maravedís)

5) encomiendas muy pequeñas (10.000-75.000 maravedís)

Entre las encomiendas de carácter extraordinario (800.0001.200.000 maravedís) sólo podrían contabilizarse tres. La lista la encabeza la encomienda mayor, que estuvo ocupada en los períodos analizados por miembros de los linajes Meneses, Sandoval, Carrillo y Guzmán. En segundo lugar se encontraba la encomienda de la Clavería, al frente de la cual estuvieron caballeros pertenecientes a las familias de los Cárdenas, Villalobos, Guzmán y Padilla. Finalmente, por razones económicas, se puede incluir dentro de las encomiendas de carácter extraordinario a la circunscripción de Otos, al frente de la cual estuvo Juan Ramírez de Guzmán y con posterioridad tal vez pudo ser ocupada por García López de Padilla ${ }^{104}$.

El segundo escalón entre las tenencias calatravas estaría ocupado por las encomiendas grandes (250.000-600.000 maravedís). En este nivel de rentas podemos incluir a las encomiendas de Almodóvar (ocupada por caballeros de los linajes Guzmán y Torres), Sevilla (López de Córdoba y Roelas), Aceca (Guzmán y Padilla), Castilserás (Angulo y Ponce de León), El Viso (Cárdenas y Padilla), Piedrabuena (Coronel, Aza, Carrillo, Valdelomar), Manzanares (Ulloa), Obrería (Barroso, Venegas) y Caracuel (Godoy, Guzmán y Carrillo) ${ }^{105}$. En este grupo podemos incluir probablemente a la encomienda de Maqueda, a pesar de que no contamos con datos correspondientes a las rentas percibidas en la segunda mitad del siglo XV, ya que Maqueda fue enajenada del patrimonio de la orden en 1434. Sin embargo los caballeros que estuvieron al frente de esta circunscripción calatrava pertene-

\footnotetext{
${ }^{103}$ Solano, La Orden de Calatrava en el siglo XV, pp. 306-308.

${ }^{104}$ RADES Y ANDRADA, Chronica de Calatrava, fols. 58v-78r.

${ }^{105}$ E. RodRíGUEZ-PICAVEA MATILla, Prosopografía de la Orden de Calatrava en Castilla. La primera mitad del siglo XV, pp. 207-240; RADES Y ANDRADA, Chronica de Calatrava, fols. $58 \mathrm{v}-78 \mathrm{r}$.
} 
cían a los linajes Carrillo y Guzmán ${ }^{106}$, familias que como hemos subrayado consiguieron disfrutar de otras encomiendas grandes y también de encomiendas de carácter extraordinario. Por otra parte, el interés que mostró por ella Álvaro de Luna y la importancia de los bienes que el condestable entregó en la permuta para conseguir el señorío sobre la villa de Maqueda y su aldea de San Silvestre, además de la villa de El Colmenar, indicarían la importancia de la encomienda de Maqueda. Por otra parte, podemos aproximarnos al valor de las rentas de esta encomienda calatrava gracias a los arrendamientos realizados antes y después de la confiscación de sus propiedades al condestable de Castilla en 1453. Así, los derechos de los herbajes de Maqueda y su vecina aldea de San Silvestre se arrendaron en 1451 por 105.000 maravedís anuales, los pechos y derechos de la villa de Maqueda se arrendaron en 1454 en 80.000 maravedís, mientras un año antes el arrendamiento de las alcabalas se valoró en 95.000 maravedís. Sólo por estas partidas, a las que hay que sumar otras de cuantías desconocidas, la encomienda de Maqueda se sitúa entre las más rentables de la orden. La cuantía de estas tres partidas se acerca a los ingresos percibidos por Álvaro de Luna en la Correduría Mayor de Sevilla, una de las más rentables fuentes de ingresos entre las muchas de las que disfrutaba el condestable ${ }^{107}$.

Las encomiendas medianas, con unas rentas comprendidas entre los 150.000-250.000 maravedís anuales, suman un total de 12: Córdoba (Angulo), Daimiel, Guadalerza (Carrillo, Guzmán), Herrera (Guzmán, Beteta, Valdelomar), Malagón (Godoy, Sotomayor, Guzmán, Coronel, Roelas), Valdepeñas (Padilla), Fuente del Emperador (Sandoval, Guzmán, Angulo, Roelas, Venegas), Moratalaz (Carrillo, Guzmán), Toledo (Sotomayor, Guzmán, Ramírez de Sevilla), Torres y Jimena (Valenzuela) ${ }^{108}$, Torre del Cañaveral y Abanilla (Segarra).

Por su parte, las encomiendas pequeñas, cuyas rentas anuales se encuentran comprendidas entre los 75.000 y 150.000 maravedís son 14: Almagro, Alcolea y Almadén, Calatrava la Vieja, Castellanos, Montanchuelos, Mestanza, Puertollano, Torroba, Auñón, Zorita, Plasencia, Martos, Víboras y Lopera.

Por último, las encomiendas muy pequeñas, con unos ingresos anuales entre 26.000 y 75.000 maravedís suman un total de nueve: Ballesteros, Ciudad Real, El Pozuelo, Almoguera, Huerta de Valdecarábanos, Vallaga, Talavera, Bélmez y Subclavería.

Además, contamos con otras dos encomiendas calatravas de las que desconocemos la cuantía de sus rentas. Se trata de la subencomienda del

\footnotetext{
${ }^{106}$ AHN, OO, MM., Calatrava, carp. 467, no 313 bis; RADES Y ANDRADA, Chronica de Calatrava, fol. $6 \overline{\mathrm{j}}_{\mathrm{v}}$.

${ }^{107}$ Vid. M.A. LADERO QUESADA, La hacienda real de Castilla en el siglo XV, La Laguna, 1973 , p. 263; J.M. CALDERON ORTEGA, Alvaro de Luna: riqueza y poder en la Castilla del siglo 1973, p. 263; J.M. CALDERON ORTH
$X V$, Madrid, 1998 , pp. 253-261.

${ }^{108}$ RADES Y ANDRADA, Chronica de Calatrava, fols. 62v-78r; E. RODRíGUEZ-PICAVEA MATILLA, Prosopografía de la Orden de Calatrava en Castilla. La primera mitad del siglo XV, pp. 207-243.
} 
Convento y de la encomienda de Sabiote. Sin embargo, parece probable que las dos pertenecieran al grupo de encomiendas pequeñas o al de las muy pequeñas.

Las encomiendas de carácter extraordinario y una parte importante de las grandes son controladas en buena medida por caballeros de la alta nobleza o pertenecientes a linajes con presencia relevante en la institución. Además, los restantes miembros de los mismos linajes solían controlar las encomiendas medianas, mientras que los demás caballeros calatravos debían conformarse con las encomiendas pequeñas o muy pequeñas, aunque algunos podían acceder también a las tenencias más apetecidas.

\section{LAS ENCOMIENDAS Y LA CUESTIÓN DE LA HERENCIA}

En este período que estamos analizando las encomiendas no se han convertido todavía, con carácter general, en hereditarias. Sólo al final del período, hacia 1450, conservamos el único ejemplo seguro de herencia de una encomienda. Se trata de la encomienda mayor de la orden de Calatrava, ocupada por Juan Ramírez de Guzmán y que, al mediar el siglo XV, fue heredada por su hijo Fernán Gómez de Guzmán ${ }^{109}$. Ciertamente esta herencia excepcional de la más importante encomienda calatrava puede explicarse en el contexto de los complejos acuerdos de 1448 mediante los cuales el comendador mayor renunciaba definitivamente a sus viejas aspiraciones al maestrazgo calatravo y reconocía a Pedro Girón como maestre ${ }^{110}$. Tal vez entre las muchas compensaciones de las que fue objeto Juan Ramírez de Guzmán para que renunciara al maestrazgo se incluyó también el compromiso de que la encomienda mayor continuara, tras su muerte, en manos de sus herederos. La otra posibilidad es que, tras la vacante dejada por su padre, el maestre Pedro Girón, probablemente después de la preceptiva aprobación del capítulo general ${ }^{111}$, concediera la encomienda mayor a Fernán Gómez de Guzmán, que en esos momentos aparecía como principal representante de su linaje en el seno de la orden. De ser así, el maestre intentaría, en cierto modo, neutralizar la potencial oposición a su liderazgo que podía representar el nuevo jefe de los Guzmán calatravos, en un momento en el que, con el apoyo de la monarquía aragonesa, todavía Alfonso de Aragón seguía defendiendo sus derechos al maestrazgo desde su consolidada posición en la encomienda mayor de Alcañiz ${ }^{112}$.

\footnotetext{
${ }^{109}$ Figuraba ya al frente de la encomienda mayor desde antes del 1 de marzo de 1452 . Vid. LÓPEZ CASAS, Fernán Gómez de Guzmán: el envés histórico de la figura del comendador de Fuenteovejuna, p. 471, nota 7. y 5 .

${ }^{110}$ Casado Quintanilla, Corona de Castilla: Documentos de la Orden de Calatrava, $\mathrm{n}^{\circ} 4$

${ }^{111}$ AyAla MARTíNeZ, Las órdenes militares hispánicas en la Edad Media, p. 279.

${ }^{112}$ SolAnO, La Orden de Calatrava en el siglo XV, pp. 89-94.
} 
Contamos además con otros dos casos referidos a la encomienda de la clavería, la segunda en importancia en el organigrama calatravo. Sin embargo se trata solamente de posibilidades no totalmente confirmadas. En primer lugar, los dos Ramiro Núñez de Guzmán que se suceden al frente de la clavería durante los maestrazgos de Gonzalo Núñez de Guzmán y Luis González de Guzmán podrían ser en realidad, como ya hemos apuntado, la misma persona. El segundo caso se refiere al linaje de los Padilla. Está documentado que Fernando de Padilla fue clavero de Calatrava hasta 1443 y que su hermano García López de Padilla ostentaba el mismo cargo en septiembre de 1445 . Es posible que en el paréntesis cronológico la clavería estuviera en posesión de otro freire calatravo ${ }^{113}$.

El único ejemplo probable de sucesión al frente de otra encomienda relacionado con miembros del mismo linaje es el que documentamos en la tenencia de Malagón, al frente de la cual estuvieron como comendadores Ramiro Núñez de Guzmán (1392) ${ }^{114}$ y Álvaro Sánchez de Guzmán (1395$1401)^{115}$. Probablemente se trata de caballeros pertenecientes a ramas distintas del prolífico linaje de los Guzmán. En todo caso, no está constatado documentalmente que Álvaro Sánchez perteneciera al linaje Guzmán y sólo conocemos su vinculación con esta familia por una referencia de Rades ${ }^{116}$.

Además disponemos de otros seis ejemplos, no de herencia, pero sí de dos miembros de un linaje ocupando la misma encomienda, aunque no se trata de un caso de patrimonialización comendataria dentro del mismo linaje, ya que entre ambos caballeros de la misma familia se intercalan freires pertenecientes a otros linajes. La mayoría de los casos conocidos afectan a la amplia familia de los Guzmán, cuyas diversas ramas son numerosas. Se trata de ejemplos referidos a las encomiendas de Aceca, Almodóvar, Caracuel, Maqueda y Villarrubia, ocupadas durante este período por dos caballeros pertenecientes al linaje Guzmán. Al margen de estos casos, sólo contamos con

\footnotetext{
${ }^{113}$ Un documento fechado en Almagro, el 24 de junio de 1444, menciona a Juan de Guzmán, fijo del sennor clavero de Calatraba e su procurador que es. Vid. Archivo Municipal de Almagro, $n^{\circ} 6$, fols. 3v-6v. Publ. L. R. VILLEGAS DíAZ, Colección de documentos del Archivo Municipal de Almagro (Ciudad Real). 1374-1498, en prensa, doc. 11 (debo el conocimiento de este documento a la generosidad del profesor Villegas, al que agradezco sinceramente que me proporcionara un ejemplar de su trabajo). ¿El clavero al que alude el documento podría ser el comendador mayor Juan Ramírez de Guzmán? El primogénito de este caballero era efectivamente Juan de Guzmán y en caso de que el documento se refiera al comendador mayor, éste pudo aprovechar la anárquica coyuntura por la que atravesaba la orden para apropiarse de la clavería y titularse también clavero, tạl vez con el consentimiento del maestre Alfonso de Aragón a cambio de la renuncia de las aspiraciones de Juan Ramírez de Guzmán al maestrazgo.

${ }^{114} \mathrm{AHN}$, OO. MM., sign. 1348 c, Registro de Escrituras de la Orden de Calatrava, VIII, fol. 22. Publ. ORTEGA Y COTES, ÁLVAREZ DE BAQUEDANO Y ORTEGA ZÚNIGA Y ARANDA, Bullarium Ordinis Militiae de Calatrava, pp. 223-224; AHN, OO. MM., Calatrava, carp. 466, no 274.

${ }^{115}$ AHN, OO. MM., Calatrava, carp. 466, n ${ }^{\circ}$ 275; Real Academia de la Historia, Colección Salazar, sign. M-130, fols. 42-44; ORTEGA Y COTES, ALVAREZ DE BAQUEDANO Y ORTEGA ZÚNIGA Y ARANDA, Bullarium Ordinis Militiae de Calatrava, pp. 224-227; AHN, OO. MM., Calatrava, carp. 466, n ${ }^{\circ} 281$.

${ }^{116}$ RADES Y ANDRADA, Chronica de Calatrava, fol. 68r.
} 
el ejemplo de la encomienda de Torroba, ocupada por dos miembros del linaje Morales, aunque no consecutivamente ${ }^{117}$.

En definitiva, no es posible constatar en este período que estamos analizando la patrimonialización de encomiendas con carácter hereditario. Admitiendo los cuatro ejemplos posibles, solo se podría afirmar la existencia de situaciones excepcionales referidas a las dos encomiendas más importantes de la orden o restringidas a los dos linajes más relevantes de la institución Guzmán y Padilla- al final del período analizado. En cualquier caso, únicamente se podría corroborar documentalmente un caso excepcional de herencia comendataria, el que se produce en la encomienda mayor, quedando los tres restantes como simples ocupaciones de encomiendas vacantes por caballeros pertenecientes al mismo linaje que el comendador anterior.

\section{CONCLUSIONES}

En conclusión, determinadas familias nobles del reino de Castilla utilizaron la orden de Calatrava como instrumento de ascenso social y económico al garantizarse la percepción de las rentas de las encomiendas. Los linajes nobiliarios con una presencia cuantitativa más destacada en la institución religioso-militar fueron los Guzmán, Padilla, Carrillo, Morales, Sandoval, Godoy, Valenzuela, Figueroa, Venegas y Beteta, aunque otras familias nobiliarias, como las de los Girón, los Villalobos y los Cárdenas, tuvieron una incidencia cualitativa más destacada en la orden calatrava. En líneas generales la introducción de estos linajes en la milicia cisterciense se originó y se consolidó en los cien años que transcurren entre el ecuador del siglo XIV y mediados de la centuria siguiente.

Por otra parte, este estudio ha permitido establecer la reorganización del patrimonio de la institución cisterciense y el reparto de los recursos de la orden en beneficio de los caballeros procedentes de la alta nobleza o pertenecientes a los linajes predominantes en el seno de la orden. Con todo, las encomiendas, cuyo disfrute permitía a los caballeros beneficiarse de una parte de los recursos de la orden, no se convirtieron en hereditarias en este período, salvo en algún caso excepcional.

La orden de Calatrava se alimentaba fundamentalmente de individuos procedentes de las filas de la baja nobleza, que cuantitativamente suponían la inmensa mayoría de los caballeros de la institución. Sin embargo, fueron generalmente los freires procedentes de la alta nobleza y de la nobleza media los que controlaron el triunvirato de poder de la orden y las encomiendas más importantes, sobresaliendo en este sentido los Guzmán y los Padilla.

\footnotetext{
${ }^{117} \mathrm{AHN}, \mathrm{OO}$. MM., Calatrava, carp. 467, no 297; AHN, OO. MM. sign. 1412c, fols. 13r y 20v; RADES Y ANDRADA, Chronica de Calatrava, fol. 70v; AHN, OO. MM., Calatrava, carp. 433 , no 255 y 256; Real Ácademia de la Historia, Colección Salazar, sign. M'-5, fol. 279; sign. M-9, fols. 281-292.
} 
Por otra parte, conviene subrayar que una parte significativa de los caballeros de la baja nobleza procedían de familias que pertenecían a las oligarquías urbanas de Toledo, Córdoba y Sevilla, tres de las ciudades más importantes del reino castellano, donde además la orden de Calatrava tenía establecidas las encomiendas urbanas más relevantes. Esta circunstancia permitía a la institución estrechar lazos con las redes de poder local.

Fecha de recepción del artículo: enero 2007.

Fecha de aceptación y versión final: abril 2007. 
EL TRIUNVIRATO DE PODER

DE LA ORDEN DE CALATRAVA

(1350-1450)

\begin{tabular}{|c|c|c|}
\hline MAESTRES & $\begin{array}{c}\text { COMENDADORES } \\
\text { MAYORES }\end{array}$ & CLAVEROS \\
\hline Juan Núñez de Prado & Pedro Estébanez Carpenteiro & Ramiro Lorenzo Gallinato \\
\hline Diego García de Padilla & Gutierre Téllez de Meneses & García López de Cárdenas \\
\hline Martín López de Córdoba & Diego Martínez & $\begin{array}{l}\text { Fernando Rodríguez de Villa- } \\
\text { lobos }\end{array}$ \\
\hline Pedro Muñiz Godoy & Pedro López de Mendo & Ramiro Núñez de Guzmán I \\
\hline Pedro Álvarez de Pereira & Gutierre Díaz de Sandoval & Ramiro Núñez de Guzmán II \\
\hline Gonzalo Núñez de Guzmán & Alonso Fernández Nieto & Fernando de Padilla \\
\hline Enrique de Villena & Luis González de Guzmán & \multirow[t]{5}{*}{ García López de Padilla } \\
\hline Luis González de Guzmán & Lope Carrillo & \\
\hline Fernando de Padilla & Juan Ramírez de Guzmán & \\
\hline Alfonso de Aragón & Fernán Gómez de Guzmán & \\
\hline Pedro Girón & & \\
\hline
\end{tabular}

\section{EL CONTROL DEL LINAJE GUZMÁN SOBRE EL TRIUNVIRATO DE PODER DE LA ORDEN DE CALATRAVA (1385-1450)}

\begin{tabular}{|c|l|l|}
\hline CRONOLOGÍA & \multicolumn{1}{|c|}{ CABALLERO } & \multicolumn{1}{|c|}{ DIGNIDAD } \\
\hline $\mathbf{1 3 8 5 - 1 4 0 4}$ & $\begin{array}{l}\text { Gonzalo Núñez de Guzmán } \\
\text { Luis González de Guzmán } \\
\text { Ramiro Núnez de Guzmán }\end{array}$ & $\begin{array}{l}\text { Maestre } \\
\text { Comendador Mayor } \\
\text { Clavero }\end{array}$ \\
\hline $\mathbf{1 4 0 4 - 1 4 1 6}$ & $\begin{array}{l}\text { Luis González de Guzmán } \\
\text { Ramiro Núñez de Guzmán }\end{array}$ & $\begin{array}{l}\text { Comendador Mayor } \\
\text { Clavero }\end{array}$ \\
\hline $\mathbf{1 4 1 6 - 1 4 4 3}$ & $\begin{array}{l}\text { Luis González de Guzmán } \\
\text { Juan Ramírez de Guzmán } \\
\text { Ramiro Núñez de Guzmán II }\end{array}$ & $\begin{array}{l}\text { Maestre } \\
\text { Comendador Mayor } \\
\text { (desde 1429) } \\
\text { Clavero }\end{array}$ \\
\hline $\mathbf{1 4 4 3 - 1 4 5 0}$ & $\begin{array}{l}\text { Juan Ramírez de Guzmán } \\
\text { Fernán Gómez de Guzmán }\end{array}$ & $\begin{array}{l}\text { Comendador Mayor } \\
\text { Comendador Mayor } \\
\text { (desde c. 1450) }\end{array}$ \\
\hline
\end{tabular}




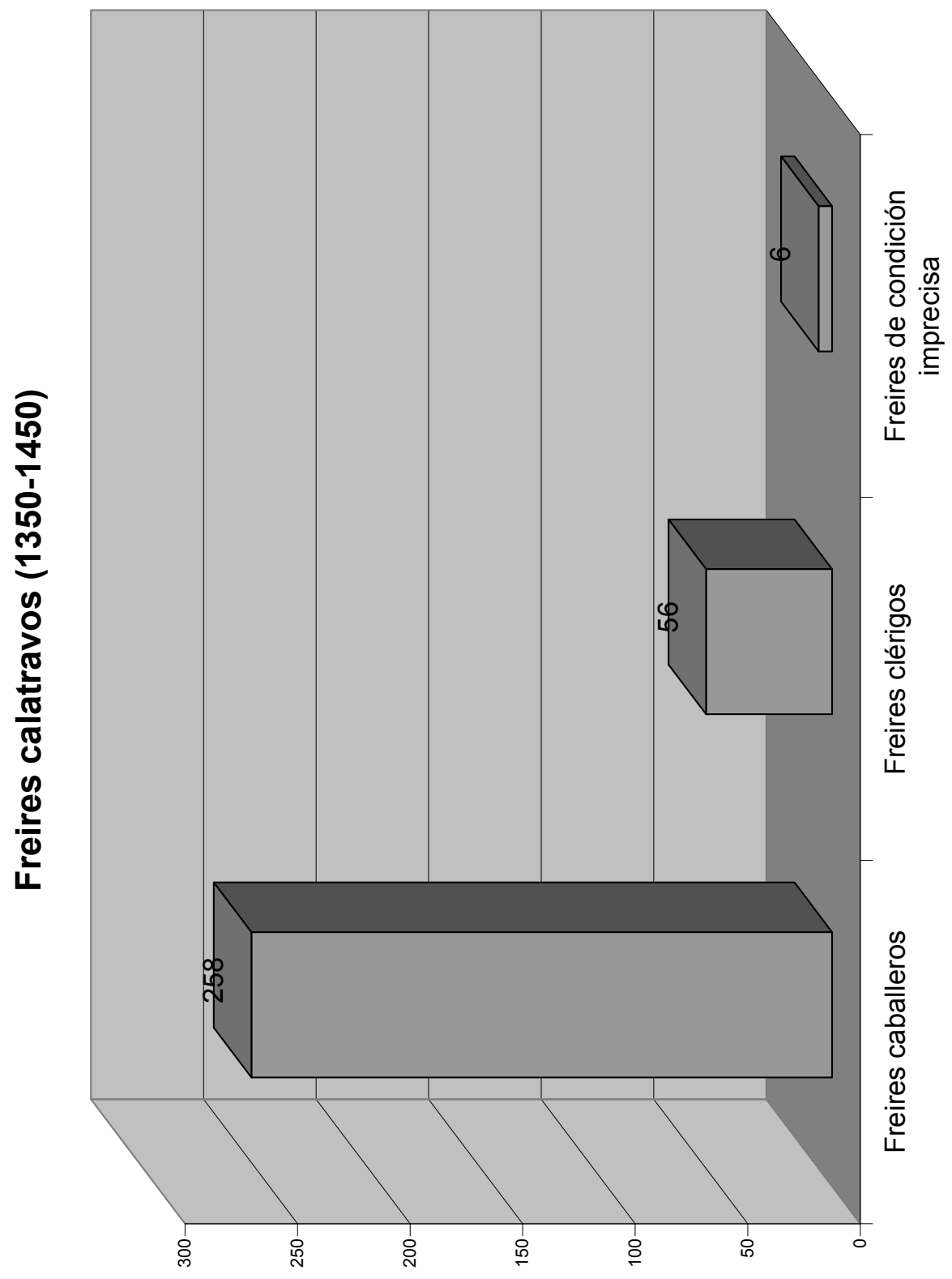



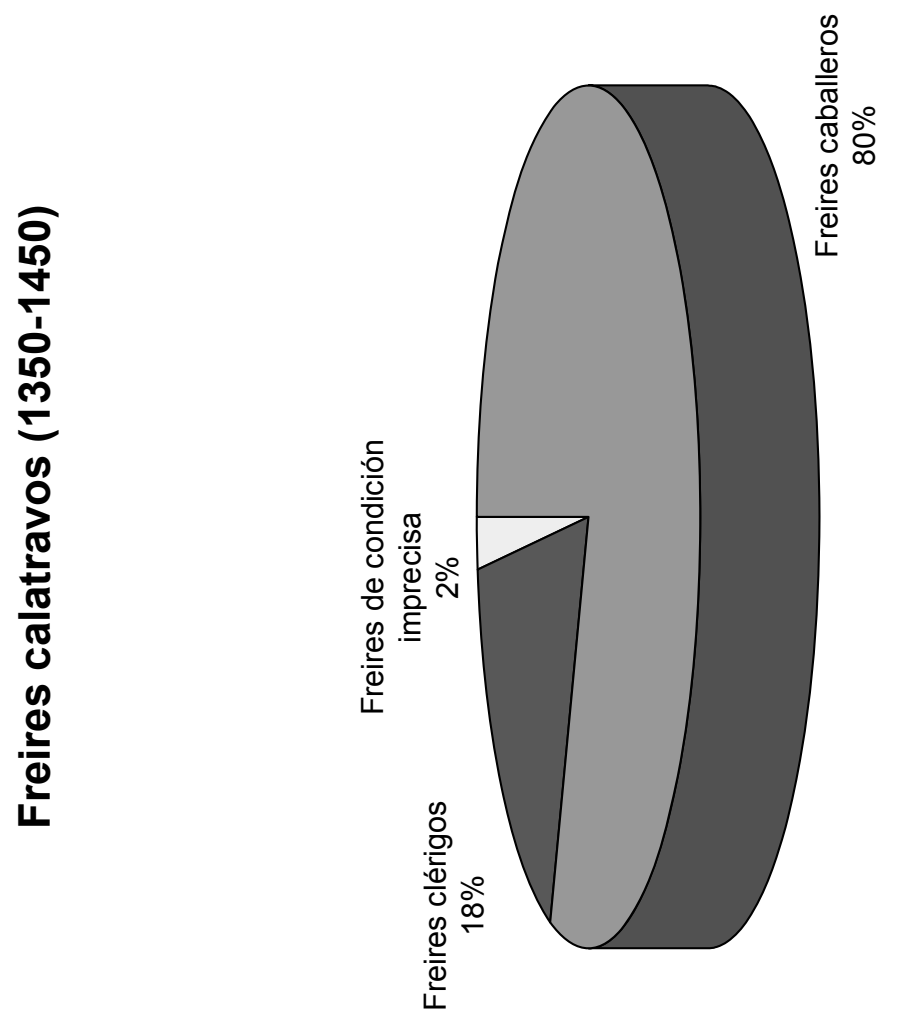


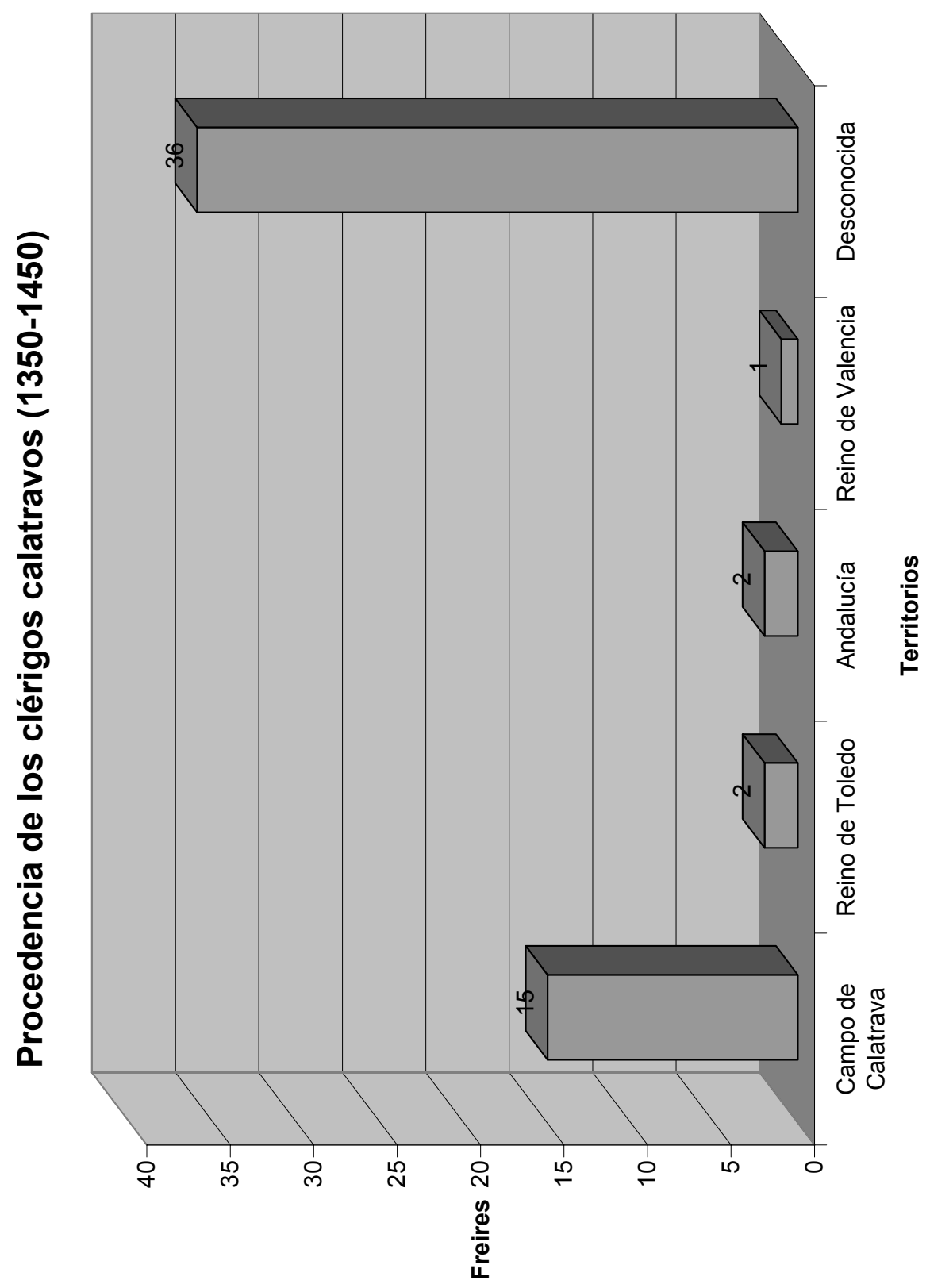



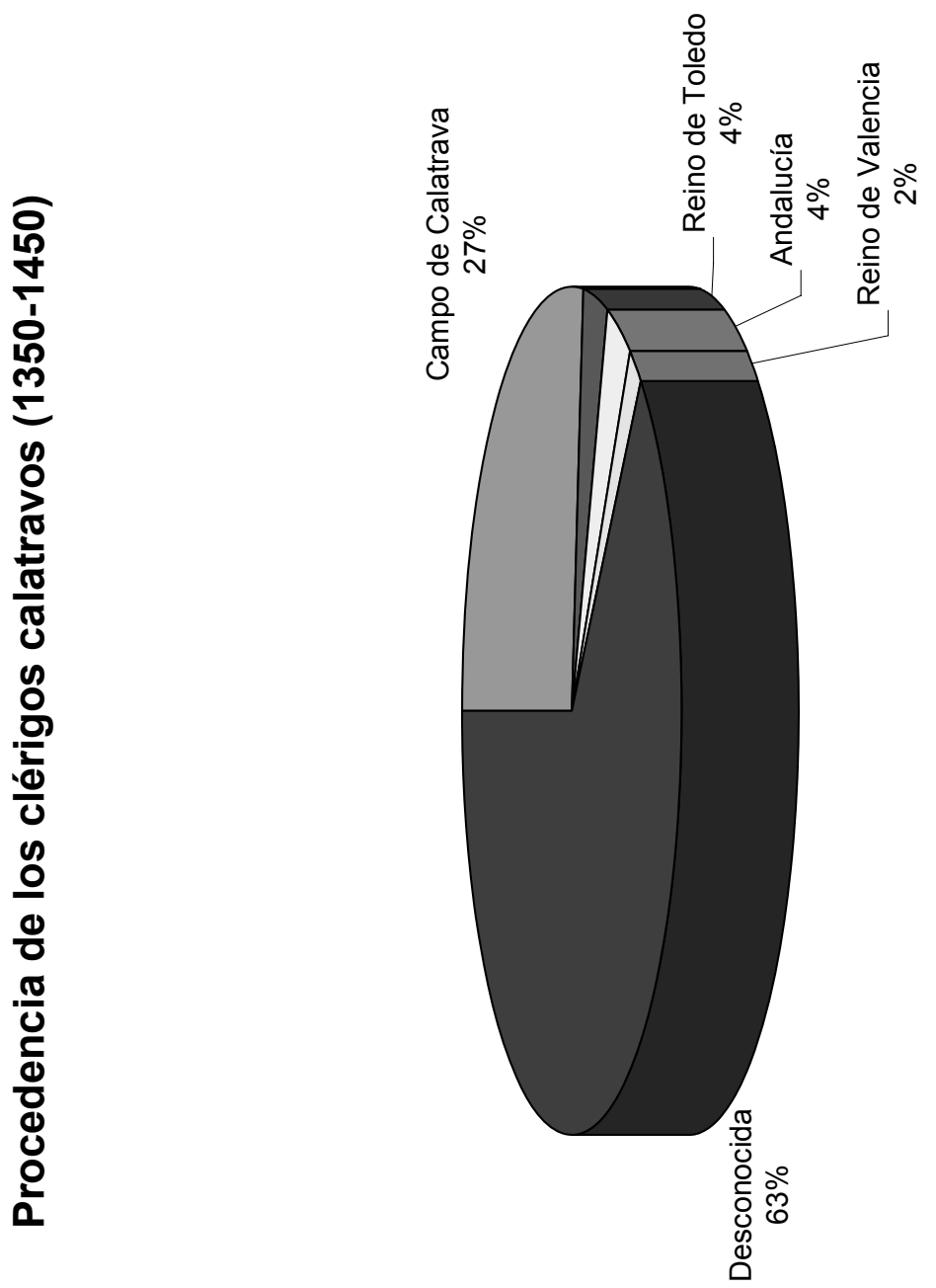


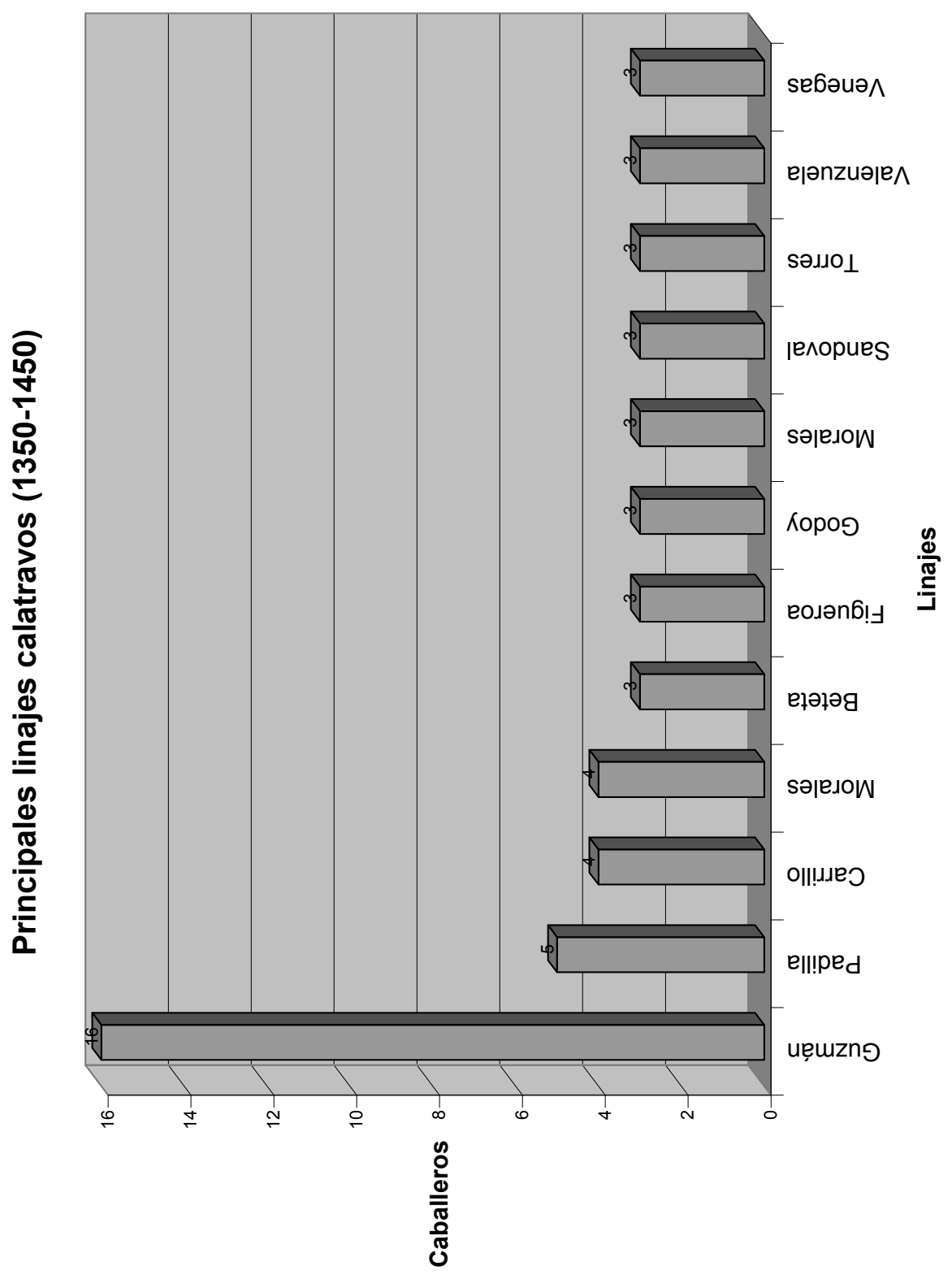




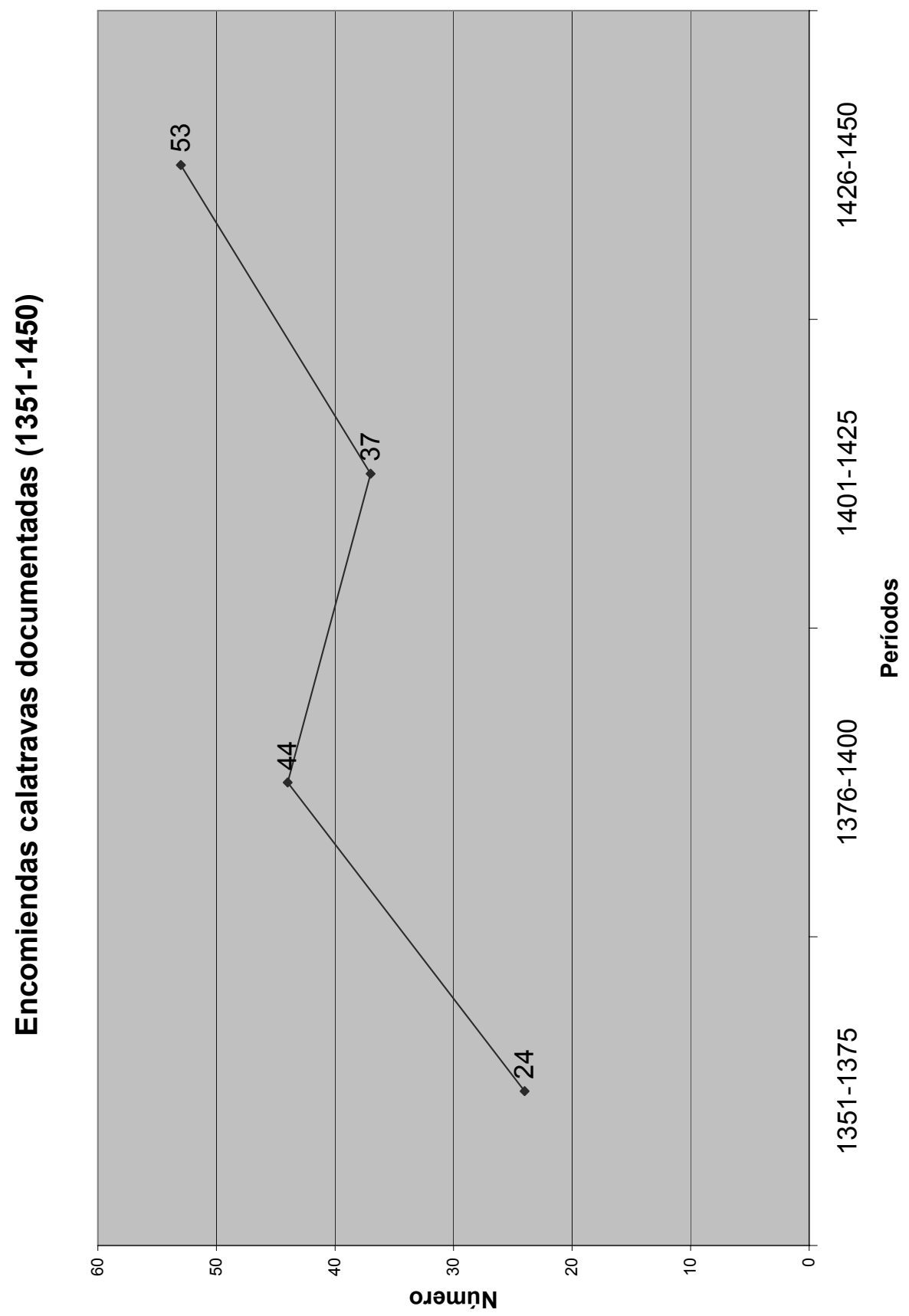



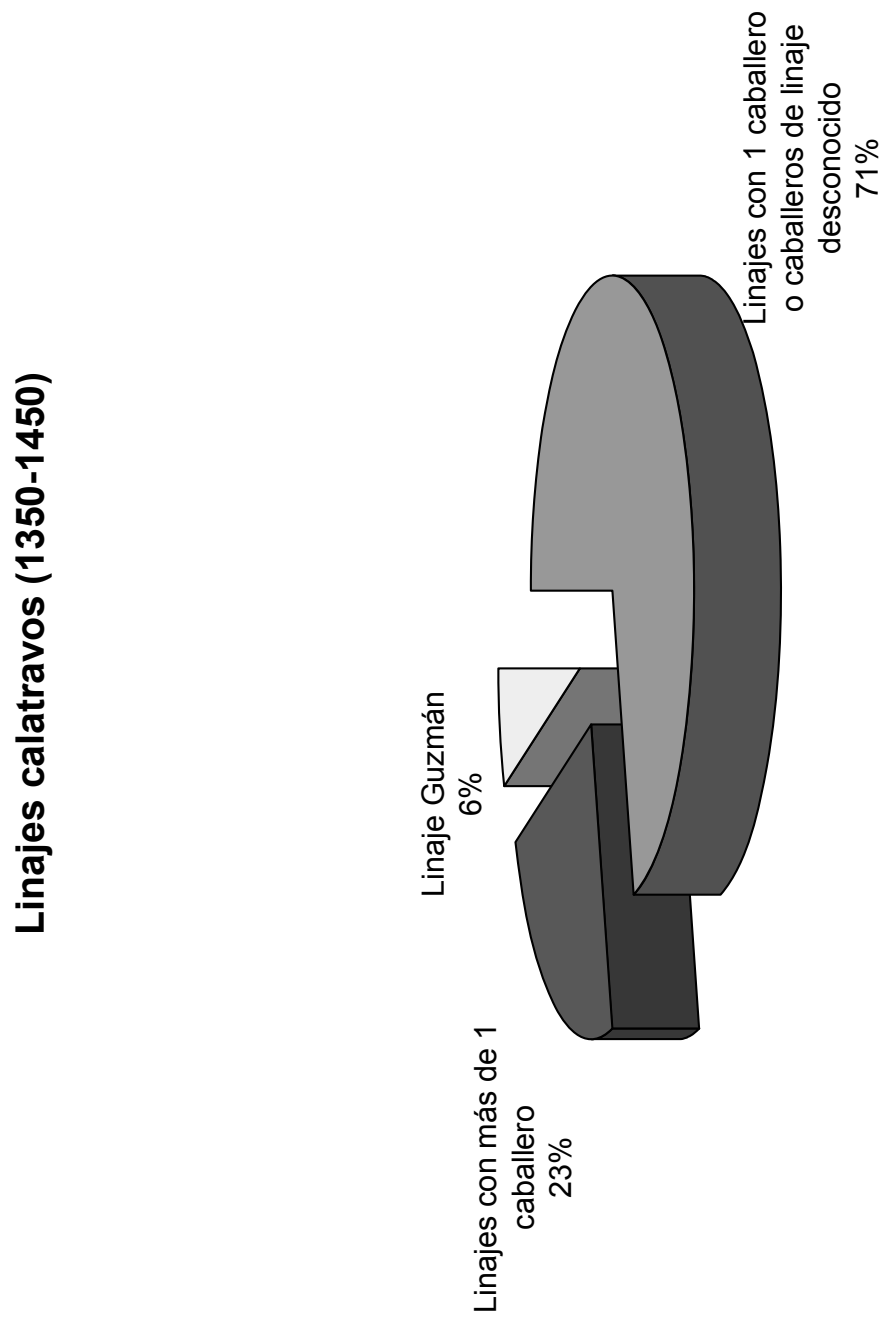